\title{
El judío en la literatura española
}

The Jew in the spanish literature

Dra. Juana Lorena Campos

Universidad de Chile

vani@uchile.cl

Chile

\section{RESUMEN}

El estudio muestra cómo ha ido evolucionando la imagen que se representaba del judío en la literatura española desde las primeras piezas literarias hasta llegar a las obras del siglo XIX. Se advierte el paso de lo feo y malo hacia el sino trágico que acompaña al judío. Este estudio es fundamentalmente descriptivo en base a la concepción estructural de los personajes.

Palabras Claves: judaísmo español - Sefarad - Literatura española - literatura judía

\begin{abstract}
The study shows how the image has evolved to represent the Jewish in Spanish literature from the earliest pieces of literature up to the nineteenth-century works. It warns the passage of the ugly and bad to the tragic fate that accompanies the Jew. This descriptive study is fundamentally based on the structural design of the characters.
\end{abstract}

Keywords: Spanish Jewry - Sefarad - Spanish Literature - Jewish Literature 


\section{Introducción al análisis textual}

Érase un hombre a una nariz pegado, érase una nariz superlativa, érase una nariz sayón y escriba, érase un peje espada muy barbado.

Quevedo

El estudio textual sobre la imagen del judío en la literatura española entre los siglos XII y XIX se centrará en la manera en que están construidos los personajes de las distintas obras del corpus que se ha recolectado. Son los personajes quienes encarnan una historia, una personalidad y una forma de ver el mundo, por lo tanto nuestro eje guía es el seguimiento de los personajes denominados como judíos en las obras consultadas. El corpus del estudio está compuesto por obras de diferentes géneros literarios; por ejemplo, canto épico, auto sacramental, lírica, teatro, cuento y novela. Para los efectos de nuestra investigación no es necesario adentrarnos en un análisis detallado de cada género y sub género, pues lo relevante es que en cada una de las obras elegidas existe una historia contada en torno a uno o varios personajes quienes dinamizan tal historia con sus acciones. Es importante destacar, también, que las obras corresponden a períodos diferentes en la historia de España y que, por lo tanto, van a responder a diferentes concepciones estéticas y semánticas, lo que se evidenciará en las distintas construcciones de personajes que podremos ir apreciando.

\subsection{El concepto de personaje y su clasificación}

Cada una de las obras del corpus contiene una historia llevada a cabo por personajes que se encuentran en un conflicto y que luego de variadas acciones llegan a un término del problema. En cada una de las historias aparece un personaje denominado como "judío". La forma en la que abordaremos el análisis del personaje judío es aplicando una distinción de aspectos que configuran a estos personajes; luego, atenderemos con detenimiento aquellos aspectos constantes y aquellos que han cambiado. A continuación presentamos un cuadro taxonómico de los diferentes aspectos relevantes del personaje. Esta clasificación se estructuró, inicialmente, a partir de las consideraciones del Diccionario de retórica, crítica y terminología literaria de Angelo Marchese y Joaquín Forradellas, ${ }^{1}$ sin embargo las distinciones 
propuestas por el reconocido trabajo de Gerard Genette $^{2}$, de Bremond ${ }^{3}$ y las novedosas consideraciones de María del Mar Forment ${ }^{4}$ han enriquecido notablemente la comprensión del concepto de personaje en nuestro estudio.

\section{Cuadro 1}

Clasificación del personaje

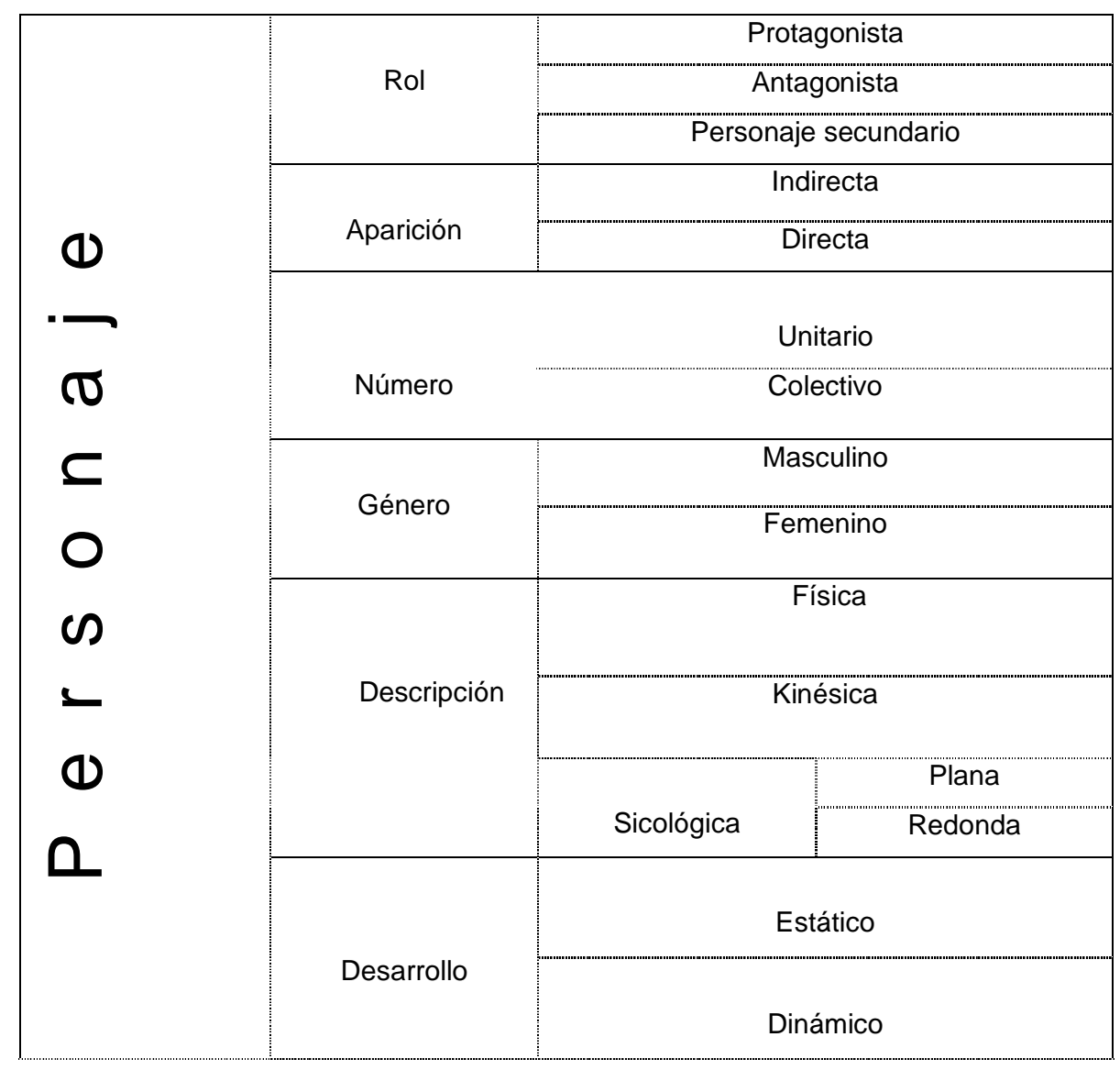




\subsection{Rol del personaje}

La primera clasificación que podemos distinguir es en cuanto al ROL que el personaje cumple en la historia. Si este personaje es el principal y eje indiscutible de la trama se le considerará el PROTAGONISTA. Si ejerce una fuerza opuesta a la fuerza que ejerce el protagonista, se le considerará el ANTAGONISTA. Ahora bien, si el personaje no cumple un rol relevante y su función es complementar la acción del protagonista o antagonista, estamos frente al PERSONAJE SECUNDARIO.

\subsection{Aparición del personaje}

La manera en que nos es presentado el personaje a los lectores/espectadores, es lo que consideramos en la clasificación como APARICIÓN; esto puede ser de manera INDIRECTA, es decir, a través de las observaciones que el narrador de la historia u otro de los personajes emite sobre nuestro personaje en cuestión, o puede ser de forma DIRECTA, es decir, el propio personaje posee discurso y a través de este discurso los lectores/espectadores accedemos a él.

\subsection{Número del personaje}

La clasificación de NÚMERO se refiere a que el personaje puede ser UNITARIO, uno, o puede ser COLECTIVO, varios bajo una denominación.

\subsection{Género del personaje}

La clasificación del GÉNERO se refiere a la distinción de personajes FEMENINOS o MASCULINOS.

\subsection{Descripción del personaje}

En relación a la DESCRIPCIÓN del personaje, es decir, a las características que el texto entrega de él, podemos distinguir la DESCRIPCIÓN FÍSICA, que habla de las características corporales y de vestimenta del personaje; la DESCRIPCIÓN KINÉSICA, que se refiere a los gestos realizados por el personaje. Esta distinción de María del Mar Forment la consideramos porque nuestros 
personajes de estudio, en muchas ocasiones son descritos sólo en cuanto a sus gesticulaciones, lo que en palabras de la autora corresponde al apoyo pragmático de la comunicación ${ }^{5}$. También es posible distinguir la DESCRIPCIÓN SICOLÓGICA, que se refiere a las características valóricas de Ios personajes. La DESCRIPCIÓN SICOLÓGICA se puede realizar de manera PLANA, es decir, si están construidos a una sola cualidad, o bien puede ser REDONDA, si la configuración psíquica es compleja y rica.

\subsection{Desarrollo del personaje}

EI DESARROLLO del personaje puede ser ESTÁTICO, es decir, el personaje empieza la historia de una forma y termina de la misma forma, lo que es habitual en los personajes secundarios. También puede ser un DESARROLLO DINÁMICO, lo cual significa que el personaje experimenta cambios en el transcurso de la historia. 


\section{Presentación del corpus de estudio}

En el siguiente cuadro presentamos el corpus de estudio.

\section{Cuadro 2}

CORPUS BIBLIOGRÁFICO

\begin{tabular}{|c|c|c|c|}
\hline OBRA & AUTOR & FECHA & $\begin{array}{l}\text { GENERO } \\
\text { LITERARIO }\end{array}$ \\
\hline El Cantar del Mío Cid & Anónimo & $\begin{array}{l}\text { Inicios del siglo } \\
\text { XII }\end{array}$ & Cantar de gesta \\
\hline $\begin{array}{l}\text { El auto de los reyes } \\
\text { magos }\end{array}$ & Anónimo & $\begin{array}{l}\text { Fines del siglo } \\
\text { XII }\end{array}$ & Auto sacramental \\
\hline $\begin{array}{l}\text { Los Milagros de Nuestra } \\
\text { Señora }\end{array}$ & Gonzalo de Berceo & Siglo XIIII & Milagro \\
\hline La danza de la muerte & Anónimo & $\begin{array}{l}\text { Fines del Siglo } \\
\text { XIV }\end{array}$ & \\
\hline Los baños de Argel & Miguel de Cervantes & 1615 & Drama \\
\hline $\begin{array}{l}\text { Las paces de los reyes y } \\
\text { la judía de Toledo }\end{array}$ & Lope de Vega & 1617 & Drama \\
\hline $\begin{array}{l}\text { El mayor monstruo del } \\
\text { mundo }\end{array}$ & Calderón de la Barca & 1637 & Drama \\
\hline La rosa de pasión & $\begin{array}{l}\text { Gustavo Adolfo } \\
\text { Bécquer }\end{array}$ & 1860 & Leyenda \\
\hline Gloria & Benito Pérez Galdós & 1876 & Novela \\
\hline
\end{tabular}

Como primera observación del corpus podemos decir que las obras son de autores ampliamente reconocidos en la tradición literaria española; como segunda observación es que de nueve obras, ocho corresponden a los géneros lírico y dramático, lo cual significa que el proceso de difusión de estas obras fue masivo, recordemos que, a diferencia de nuestros días, el teatro era un evento popular y la poesía era recitada en público, con uso de herramientas mnemotécnicas. La tercera observación que se puede destacar es que "El Cantar del Mío Cid" y "El auto de los reyes magos" son obras fundacionales en la tradición literaria española, consecuentemente serán obras de constante evocación y referencia. Francisco Rico $^{6}$ plantea que lo clásico de la literatura española 
descansa en el principio de reiteración de sus piezas poéticas primigenias, y si bien esta distinción la aplica fundamentalmente al género lírico, creemos que en el transcurso de la exposición de nuestros hallazgos podremos ver cómo este principio de reiteración abarcará también a las obras dramáticas y narrativas.

\subsection{Presentación y análisis de las obras}

\subsubsection{El Cantar del Mío Cid ${ }^{7}$}

Este texto data aproximadamente del siglo XII. De autor anónimo es considerado como un monumento a la literatura española en lengua romance y se piensa que fue escrito en 1140 , cuarenta años después de la muerte del Mío Cid.

El cantar se estructura en torno al personaje del Mío Cid Campeador, es el caballero cristiano por excelencia, ilustre, sonriente, valiente, cuya existencia es una verdadera bendición para la humanidad, y por eso es venerado y alabado. Condenado al destierro, conserva el porte de un gran caballero, y aunque vencido y empobrecido, seguirá siendo siempre el Mío Cid Campeador (mi Señor vencedor), que en buena hora nació. El Cid, vasallo del rey Alfonso es desterrado injustamente. Al partir de ese momento necesita dinero para el mantenimiento de su familia y suyo propio, sin embargo el rey ha mandado que no se le ayude. Es aquí donde aparecen los personajes judíos. El episodio de las "Arcas de Arena" ha sido estudiado como un detalle humorístico, a pesar de ser un episodio en que el Cid quiebra su moral cristiana al engañar a los prestamistas, también se ha explicado este episodio como un necesario ardid para sobreponerse al mal momento que se estaba sufriendo ${ }^{8}$. El Cid le pide ayuda a su buen amigo Martín Antolinez, quien deberá tratar con los prestamistas y hacer realidad el ardid maquinado por el Cid: 
Versión original ${ }^{9}$

Fablo mio Çid el que en buen ora çinxo espada:

"¡Martin Antolinez sodes ardida lança!

Si yo bivo doblar vos he la soldada.

Espeso e el oro e toda la plata;

bien lo vedes que yo no trayo nada,

e huebos me serie pora toda mi compaña;

fer lo he amidos, de grado non avrie nada.

Con vuestro consego bastir quiero dos archas;

incamos las d'arena ca bien seran pesadas,

cubiertas de guadalmeçi e bien enclaveadas.

Los guadameçis vermejos e los clavos bien dorados.

Por Rachel e Vidas vayades me privado; quando en Burgos me vedaron compra y el rey me a airado, non puedo traer el aver ca mucho es pesado,

enpeñar gelo he por lo que fuere guisado.

De noche lo lieven que non lo vean christianos; vealo el Criador con todos los sos santos, vo mas non puedo e amidos lo fago."
Versión moderna ${ }^{10}$

Habla entonces Mío Cid, que en buen hora ciñó espada: "¡Oh buen Martín Antolínez, el de la valiente lanza!"

Si Dios me da vida he de doblaros la soldada.

Ahora ya tengo gastado todo mi oro y mi plata,

bien veis, Martín Antolínez, que ya no me queda nada.

Plata y oro necesito para toda mi compaña,

No me lo darán de grado, lo he de sacar por las malas.

Martín, con vuestro consejo hacer quisiera dos arcas,

Las llenaremos de arena por que sean muy pesadas,

bien guarnecidas de oro y de clavos adornadas.

Bermejo ha de ser el cuero y los clavos bien dorados. Buscadme a Raquel y Vidas, decid que voy desterrado por el rey y que aquí en Burgos el comprar me está vedado. Que mis bienes pesan mucho y no podría llevármelos, yo por lo que sea justo se los dejaré empeñados.

Que me juzgue el Creador, y que me juzguen sus santos, no puedo hacer otra cosa, muy a la fuerza lo hago.

Por un lado, podemos decir que el ROL DE LOS PERSONAJES es SECUNDARIO; el Cid es indiscutiblemente el Protagonista y Rachel y Vidas cooperan en su empresa, no presentarán oposiciones antagónicas. Por otro lado, se evidencia en los versos expuestos que el NÚMERO DEL PERSONAJE ES COLECTIVO, pues Rachel y Vidas aparecen en bloque, y así seguirá ocurriendo a lo largo del episodio; no hay individualización de cada uno sino que ambos son un todo. EI GÉNERO de este PERSONAJE es MASCULINO y FEMENINO.

En los dos últimos versos se evidencia la cristiandad del Mío Cid, pues sabe que el engaño no está bien. Martín Antolinez cumple la empresa que le encomienda el Campeador y sale a toda prisa en busca de los judíos prestamistas Rachel y Vidas: 


\section{Versión original}

Rachel e Vidas en uno estavan amos en cuenta de sus averes, de los que avien ganados. Lego Martin Antolinez a guisa de menbrado: "¿O sodes, Rachel e Vidas, los mios amigos caros? En poridad fablar querria con amos." Non lo detardan, todos tres se apartaron: "Rachel e Vidas: amos me dat las manos que non me descubrades a moros nin a christianos; por siempre vos fare ricos, que non seades menguados. El Campeador por las parias fue entrado, grandes averes priso e mucho sobejanos; retovo dellos quanto que fue algo,

por en vino a aquesto por que fue acusado.

Tiene dos arcas lennas de oro esmerado.

Ya lo vedes que el rey le a airado.

Dexado ha heredades e casas e palaçios;

aquelas non las puede levar, si non, ser ien ventadas

el Campeador dexar las ha en vuestra mano,

e prestalde de aver lo que sea guisado.

Prended las archas e meted las en vuestro salvo; con grand jura meted i las fes amos que non las catedes en todo aqueste año."

Rachel e Vidas seyen se consejando:

"Nos huebos avemos en todo de ganar algo.

Bien lo sabemos que el algo gaño,

quando a tierra de moros entro que grant aver saco

non duerme sin sospecha qui aver trae monedado.

Estas archas prendamos las amas,

en logar las metamos que non sean ventadas.

Mas dezid nos del Çid: ¿de que sera pagado

o que ganançia nos dara por todo aqueste año?"

Respuso Martin Antolinez a guisa de menbrado:

"Mio Çid querra lo que ssea aguisado,

pedir vos a poco por dexar so aver en salvo;

acogen sele omnes de todas partes menguados:

a menester seis cientos marcos."

Dixo Rachel e Vidas: "Dar gelos hemos de grado."

"Ya vedes que entra la noch, el Çid es presurado

huebos avemos que nos dedes los marchos.

Dixo Rachel e Vidas: "Non se faze assi el mercado,

si non primero prendiendo e despues dando."

Dixo Martin Antolinez: "Yo desso me pago.

Amos tred al Campeador contado

e nos vos ayudaremos que assi es aguisado

por aduzir las archas e meter las en vuestro salvo, que non lo sepan moros nin christianos." Dixo Rachel e Vidas: "Nos desto nos pagamos las archas aduchas, prendet seyes çientos marcos." Martin Antolinez cavalgo privado

con Rachel e Vidas de voluntad e de grado.

Non viene a la pueent ca por el agua a passado

que gelo non ventaj $n_{i}$ ssen de Burgos omne nado. Afevos los a la tienda del Campeador contado: assi commo entraron al Çid besaron le las manos, sonrrisos mio Cid, estavalos fablando:

"¡Ya don Rachel e Vidas avedes me olbidado!

Ya me exco de tierra ca del rey so airado:

a lo quem semeja de lo mio avredes algo

mientras que vivades non seredes menguados."

Don Rachel e Vidas a mio Cid besaron le las manos.

Martin Antolinez el pleito a parado

que sobre aquelas archas dar le ien vi çientos marcos e bien gelas guardarien fasta cabo del año:

ca assil dieran la fe e gelo avien jurado

que si antes las catassen que fuessen perjurados,

non les diesse mio Çid de la ganançia un dinero malo.

Dixo Martin Antolinez: "Cargen las archas privado.

Levaldas, Rachel e Vidas, poned las en vuestro salvo; yo ire con vusco que adugamos los marcos,

ca a mover a mio Cid ante que cante el gallo."

Al cargar de las archas veriedes gozo tanto:

non las podien poner en somo mager eran esforçados,
Versión moderna

A los judíos encuentra cuando estaban ocupados en contar esas riquezas que entre los dos se ganaron. Les saluda el burgalés, muy atento y muy taimado: "¿Cómo estáis, Raquel y Vidas, amigos míos tan caros? En secreto yo querría hablar con los dos un rato". No le hicieron esperar; en un rincón se apartaron. "Mis buenos Raquel y Vidas, vengan, vengan esas manos, guardadme bien el secreto, sea a moro o a cristiano, que os tengo que hacer ricos y nada habrá de faltaros. De cobrar parias a moros el rey al Cid le ha encargado, grandes riquezas cogió, y caudales muy preciados, pero luego se quedó con lo que valía algo, y por eso se ve ahora de tanto mal acusado. En dos arcas muy repletas tiene oro fino guardado. Ya sabéis que don Alfonso de nuestra tierra le ha echado, quí se deja heredades, y sus casas y palacios, no puede llevar las arcas, que le costaría caro, el Campeador querría dejarlas en vuestras manos empeñadas, y que, en cambio, les deis dinero prestado. Coged las arcas del Cid, ponedlas a buen recaudo, pero eso tiene que ser con juramento prestado que no las habéis de abrir en lo que queda de año." Raquel y Vidas están un rato cuchicheando: "En este negocio hemos de sacar nosotros algo. Cuando el Cid cobró las parias, mucho dinero ha ganado, de allá de tierra de moros gran riqueza se ha sacado. Quien muchos caudales lleva nunca duerme descansado. Quedémonos con las arcas, buen negocio haremos ambos, pondremos este tesoro donde nadie pueda hallarlo. Pero queremos saber qué nos pide el Cid en cambio y qué ganancia tendremos nosotros por este año." Dice Martín Antolínez, muy prudente y muy taimado: "Muy razonable será Mío Cid en este trato: poco os ha de pedir por dejar su haber en salvo. Muchos hombres se le juntan y todos necesitados, el Cid tiene menester ahora de seiscientos marcos." Dijeron Raquel y Vidas: "Se los daremos de grado". "El Cid tiene mucha prisa, la noche se va acercando, necesitamos tener pronto los seiscientos marcos". Dijeron Raque y Vidas: "No se hacen así los tratos, sino cogiendo primero, cuando se ha cogido dando". Dijo Martín Antolínez: "No tengo ningún reparo, venid conmigo, que sepa el Cid lo que se ha ajustado $y$, como es justo, después nosotros os ayudamos a traer aquí las arcas y ponerlas a resguardo, con tal sigilo que en Burgos no se entere ser humano". Dijeron Raquel y Vidas: "Conformes los dos estamos. En cuanto traigan las arcas tendréis los seiscientos marcos". El buen Martín Antolínez muy de prisa ha cabalgado, van con él Raquel y Vidas, tan satisfechos del trato. No quieren pasar el puente, por el agua atravesaron para que no lo supiera en Burgos ningún cristiano. Aquí veis cómo a la tienda del famoso Cid llegaron; al entrar fueron los dos a besar al Cid las manos. Sonrióse Mío Cid, y así comenzara a hablarlos: "Sí, don Raquel y don Vidas, ya me habíais olvidado. Yo me marcho de Castilla porque el rey me ha desterrado.

De aquello que yo ganare habrá de tocaros algo, y nada os faltará, mientras que viváis, a ambos". Entonces Raquel y Vidas van besarles las manos. Martín Antolínez tiene el trato bien ajustado de que por aquellas arcas les darán seiscientos marcos, bien se las han de guardar hasta el cabo de aquel año, y prometido tenían y así lo habían jurado, que si las abrieran antes queden por perjuros malos y no les dé en interés don Rodrigo ni un ochavo. Dijo Martín Antolínez: "Raquel y Vidas, lleváos las dos arcas cuanto antes y ponedlas a resguardo, yo con vosotros iré para que me deis los marcos, que ha de salir Mío Cid antes de que cante el gallo." ¡Que alegres que se ponían cuando los cofres cargaron! Forzudos son, mas cargarlos les costó mucho trabajo. Ya se alegran los judíos en los dineros pensando, para el resto de sus días por muy ricos se juzgaron. 
En los versos presentados observamos que Rachel y Vidas son personajes de APARICIÓN DIRECTA y DIRECTA, pues ellos son presentados por el juglar y, además, tienen un pequeño discurso que nos permite tener una idea de cómo son. Este discurso más la situación desarrollada nos revela la DESCRIPCIÓN de estos personajes. No contamos con DESCRIPCIÓN FÍSICA de Rachel y Vidas, pero sí de DESCRIPCIÓN KINÉSICA, la que podemos obtener gracias a los siguientes versos:

Versión original

"Rachel e Vidas en uno estavan amos en cuenta de sus averes, de los que avien ganados."

"Al cargar de las archas veriedes gozo tanto: non las podien poner en somo mager eran esforçados, Gradan se Rachel e Vidas con averes monedados, ca mientra que visquiessen refechos eran amos."
Versión moderna

A los judíos encuentra cuando estaban ocupados en contar esas riquezas que entre los dos se ganaron.

Estos versos revelan una postura corporal frente al dinero, la que se refuerza con lo que dicen, en sus pocos parlamentos:

Versión original

Rachel e Vidas seyen se consejando:

"Nos huebos avemos en todo de ganar algo.

Bien lo sabemos que el algo gaño,

quando a tierra de moros entro que grant aver saco;

non duerme sin sospecha qui aver trae monedado.

Estas archas prendamos las amas,

en logar las metamos que non sean ventadas.

Mas dezid nos del Çid: ¿de que sera pagado,

o que ganançia nos dara por todo aqueste año?"
Versión moderna

Raquel y Vidas están un rato cuchicheando:

"En este negocio hemos de sacar nosotros algo.

Cuando el Cid cobró las parias, mucho dinero ha ganado, de allá de tierra de moros gran riqueza se ha sacado.

Quien muchos caudales lleva nunca duerme descansado.

Quedémonos con las arcas, buen negocio haremos ambos, pondremos este tesoro donde nadie pueda hallarlo. Pero queremos saber qué nos pide el Cid en cambio y qué ganancia tendremos nosotros por este año."
Dixo Rachel e Vidas: "Dar gelos hemos de grado." "Ya vedes que entra la noch, el Cid es presurado; huebos avemos que nos dedes los marchos." Dixo Rachel e Vidas: "Non se faze assi el mercado, si non primero prendiendo e despues dando."

Dixo Rachel e Vidas: "Nos desto nos pagamos; las archas aduchas, prendet seyes çientos marcos."
Dijeron Raquel y Vidas: "Se los daremos de grado". "El Cid tiene mucha prisa, la noche se va acercando, necesitamos tener pronto los seiscientos marcos". Dijeron Raque y Vidas: "No se hacen así los tratos, sino cogiendo primero, cuando se ha cogido dando".

Dijeron Raquel y Vidas: "Conformes los dos estamos. En cuanto traigan las arcas tendréis los seiscientos marcos". 
En relación a estos versos podemos acceder a la DESCRIPCIÓN SICOLÓGICA y decir que Rachel y Vidas son personajes avaros, ambiciosos, amantes del dinero. Las características solo giran en torno al dinero, por lo tanto la DESCRIPCIÓN SICOLÓGICA es PLANA.

También observamos que el DESARROLLO de los personajes es ESTÁTICO, pues solo cumplen la función de prestamistas sin conflictos internos. Sin embargo esta actitud es muy importante para el desarrollo de la historia, pues gracias a ellos el Cid logra reunir dinero para su empresa. Además, es indiscutible que la avaricia de estos personajes empaña el engaño del Cid, y de esta manera el Mío Cid continúa siendo un caballero, a pesar del engaño cometido.

\subsubsection{El Auto de los Reyes Magos ${ }^{11}$}

Es la pieza más antigua del teatro español, data de fines del S. XII y fue hallada en la Catedral de Toledo en el S. XIII; consta de 147 versos, divididos en 5 escenas en torno al nacimiento de Cristo. Su trama es comparable al relato expuesto en el Evangelio de San Mateo Capítulo 2, versículos 1 al 12, en el cual los reyes magos son guiados por una estrella en busca del Mesías. Sin embargo el relato del Evangelio es un relato dogmático que resalta lo divino del nacimiento de Jesús; quizás lo único humano es el interés de Herodes por matar a este supuesto Mesías. El relato del "Auto de los Reyes Magos", por el contrario, es un diálogo con la conciencia, pues se plantea la duda sobre la existencia del Mesías. Leemos en la primea escena: 
Versión original

\author{
[Escena I] \\ [CASPAR] [Solo.] \\ ¡Dios criador, cuál maravila \\ no sé cuál es aquesta strela! \\ Agora primas la he veída; \\ poco tiempo ha que es nacida. \\ ¿Nacido es el Criador \\ que es de la[s] gentes Senior? \\ Non es verdad, no sé qué digo; \\ todo esto non vale un figo. \\ Otra nocte me lo cataré, \\ si es verdad bine lo sabré. \\ [Pausa.] \\ ¿Bine es verdad lo que yo digo? \\ En todo, en todo lo prohío. \\ ¿Non pudet seer otra sennal? \\ Aquesto es i non es ál; \\ nacido es Dios, por ver, de fembra \\ in aquest mes de december. \\ Alá iré; ó que fure, aoralo he; \\ por Dios de todos lo terné.
}

[BALTHASAR] [Solo.]

Esta strela non sé dónd vinet,

quín la trae o quín la tine.

¿Por qué es aquesta sennal?

En mos días non vi atal.

Certas nacido es en tirra

aquel qui en pace y en guerra

senior ha a seer da oriente

de todos hata in occidente.

Por tres noches me lo veré

y más de vere lo sabré.

[Pausa.]

¿En todo, en todo es nacido?

Non sé si algo he veído.

Iré, lo aoraré,

y pregaré y rogaré.

[BALTHASAR] [Solo.]

Val, Criador, atal facinda

¿fu nuncas alguandre falada

o en escriptura trubada?

Tal estrela non es in celo,

d'esto só yo bono strelero.

Bine lo veo sines escarno

que uno omne es nascido de carne,

que es senior de todo el mundo,

así cumo el cilo es redondo.

De todas gentes senior será

y todo seglo jugará

¿Es? ¿Non es?

Cudo que verdad es.

Veerlo he otra vegada,

si es vertad o si es nada.

[Pausa.]

Nacido es el Criador

de todas las gentes mayor.

Bine lo veo que es verdad;

iré alá, por caridad.

\section{Versión moderna}

1. ESCENA PRIMERA

a) Monólogo de GASPAR.

¡Dios creador, qué maravilla,

no sé cuál es esa estrella!

La acabo de ver por primera vez

y hace poco que apareció.

¿Ha nacido el Creador

que es de los pueblos Señor?

No, no es verdad; no sé qué digo;

todo esto no vale un higo.

Otra noche la observaré;

si es la estrella, bien lo sabré.

(Tras una pausa.)

Bien es verdad lo que yo digo

en todo, en todo lo aseguro.

(Una breve vacilación.)

¿No pudiera ser otra señal? (Tras nueva pausa.)

Eso no es sino lo que pienso.

Ha nacido Dios de mujer

en ese mes de diciembre.

Iré donde esté para adorarlo,

y por Dios de todos lo tendré.

b) Monólogo de BALTASAR.

Esa estrella no sé de dónde procede,

quién la ha mandado o quién la detiene.

¿Qué significa su aparición?

En toda mi vida no he visto cosa tal.

¿Ciertamente ha nacido en la Tierra

aquel que en la paz y en la guerra

ha de ser Señor de Todos

desde Oriente hasta Occidente? (Tras una pausa)

¿En todo, en todo ha nacido?

No sé si he visto algo.

(Después de otra pausa)

Iré, lo adoraré,

rezaré e imploraré.

c) Monólogo de MELCHOR

Válgame Dios, ¿ha ocurrido

antes cosa como esta

o hay noticia escrita de ella?

Tal estrella no estaba antes en el cielo,

esto lo sostengo yo, que soy buen estrellero.

Bien lo veo, sin duda alguna,

que un hombre de carne y hueso ha nacido

llamado a ser Señor de todo el mundo

así como el cielo es redondo;

de todos los pueblos será Señor

y para siempre será el Supremo Juez.

(Tras una pausa.)

¿Es [la estrella]? ¿No es?

Creo de verdad que es.

(De nuevo, la duda.)

Verla he otra vez

para saber si es o no verdad.

(Otra pausa.)

Nacido es el Creador,

que de toda la humanidad es Señor.

Bien veo que es verdad.

Iré allá por caridad. 
Esta primera escena en que los reyes se cuestionan si la estrella es señal del nacimiento del Mesías, concluye con la confirmación de que es verdad la señal. El auto es una charla humana acerca de lo divino, y en este contexto son invitados los rabinos, hombres sabios quienes conocen los escritos sagrados, para ratificar la ciencia de los reyes magos quienes afirman que el Mesías ha nacido. Leemos en la quinta escena:

Versión original

Escena V

[Salen LOS SABIOS de la corte.]

\section{[LOS SABIOS]}

Rey, ¿qué te plaze? Henos venidos.

\section{[HERODES]}

¿Ý traedes vostros escriptos?

\section{[LOS SABIOS]}

Rey, sí, traemos,

los mejores que nós havemos.

\section{[HERODES]}

Pus catad,

dezidme la vertad,

si es aquel omne nacido

que estos tres rees m'han dicho.

$\mathrm{Di}$, rabí, la vertad, si tú lo has sabido.

\section{[EL RABÍ]}

Por veras vo[s] lo digo que no lo fallo escripto.

\section{[OTRO RABÍ] (Al 1.․)}

Hamihala, ¡cúmo eres enartado! ¿Por qué eres rabí clamado? Non entendes las profecías, las que nos dixo Jeremías.

¡Par mi ley, nos somos erados!

¿Por qué non somos acordados?

¿Por qué non dezimos vertad?

[RABÍ 1.ำ]

Yo non la sé, por caridad.

[RABÍ 2.ำ

Porque no la havemos usada. ni en nostras vocas es falada.
Versión moderna

\section{ESCENA QUINTA}

a) Uno de los CONSEJEROS, a HERODES.

Rey, ¿qué queréis? Aquí estamos todos.

b) HERODES.

¿Y traéis vuestros libros?

c) Los CONSEJEROS.

Sí, rey, los traemos.

los mejores que tenemos.

d) HERODES.

Pues mirad

y decidme la verdad,

si ha nacido ese hombre

de que los tres reyes me han dicho.

Decid, rabí, la verdad, si vos la habéis sabido.

e) EL RABINO interpelado.

De verdad os digo

que no lo hallo escrito.

f) Otro RABINO, dirigiéndose al que habló antes.

¡Voto va! ¡Cómo estáis confundido!

¿Por qué os llaman rabí [si no lo sois]?

No entendéis las profecías,

las que nos dejó Jeremías.

A fe mía que nos empeñamos en el error.

¿Por qué no actuar de concierto?

¿Por qué no decir la verdad?

g) EL RABINO que habló primero.

Yo no la sé, por amor de Dios.

h) RABINO que increpa al anterior.

Porque no la practicamos

ni decimos claramente

lo que sabemos o sentimos. 
A diferencia de la primera escena donde los reyes concluyen unánimemente una verdad, en la quinta escena se evidencia la incongruencia del pensamiento judío. Herodes pide consejo a la entidad que se piensa es sabia, pero esta entidad no es homogénea, un rabino desconoce el nacimiento del Mesías, el otro la valida y descalifica a su par vehementemente:

[OTRO RABí] (Al 1.ํ)

Hamihala, ¡cúmo eres enartado!

¿Por qué eres rabí clamado?

Non entendes las profecías,

las que nos dixo Jeremías.

¡Par mi ley, nos somos erados!

¿Por qué non somos acordados?

¿Por qué non dezimos vertad? f) Otro RABINO, dirigiéndose al que habló antes.

¡Voto va! ¡Cómo estáis confundido!

¿Por qué os llaman rabí [si no lo sois]?

No entendéis las profecías,

las que nos dejó Jeremías.

A fe mía que nos empeñamos en el error.

¿Por qué no actuar de concierto?

¿Por qué no decir la verdad?

Podemos decir que el ROL de los rabinos es SECUNDARIO, que tienen una APARICIÓN DIRECTA (a través de sus parlamentos), que son un personaje de NÚMERO COLECTIVO y GÉNERO MASCULINO. En cuanto a la DESCRIPCIÓN, tenemos datos para realizar una DESCRIPCIÓN SICOLÓGICA, pues de sus diálogos se puede deducir con facilidad que son personajes indecisos, no letrados, confundidos, errados y que ocultan la verdad. Esta DESCRIPCIÓN SICOLÓGICA es PLANA, pues no se evidencian grandes matices o quiebres en la estructura sicológica de estos personajes. EI DESARROLLO es ESTÁTICO, ya que su única aparición es de confusión respecto a la validez del Mesías. El conflicto entre los rabinos refuerza la imagen divina de Jesús porque los rabinos son representantes del Judaísmo y al no rechazarlo completamente validan su divinidad. Esto para la trama del auto sacramental es de gran refuerzo argumentativo.

\subsubsection{Los Milagros de Nuestra Señora ${ }^{12}$}

"Los Milagros de Nuestra Señora"13 (S. XIII) es una de las principales obras de la literatura medieval española. Gonzalo de Berceo, su autor, dedicó su talento artístico, inteligencia y devoción religiosa a proclamar la magnificencia de la Virgen María y de los santos de la fe católica. 
"Los Milagros de Nuestra Señora" se estructura en torno a una introducción y a veinticinco relatos versificados. El verso alejandrino de esta obra cumple, por un lado, una función estética y, por otro, una función pedagógica, pues la rima consonántica que contiene es un recurso fonológico que estimula la memoria de lo escuchado o leído.

El milagro como sub género lírico se originó a partir de los exampla, especie de narración ejemplificadora que servía en la misa para introducir una verdad teológica. Esta práctica fue adquiriendo sofisticación y cultores, entre los cuales el más prodigioso en España fue Gonzalo de Berceo. Este autor junto con adherir a las técnicas del milagro y de la versificación alejandrina con gran diligencia y creatividad, participó de la fe marianista, la cual consiste en un catolicismo que centra su mirada en la figura de la Virgen María como mediadora entre el pecador y Jesucristo.

Los milagros de Berceo cuentan cómo la Virgen salva a los pecadores de su propia maldad. Desfilan frente a ella hombres, mujeres y niños de distintas condiciones sociales, religiosas e intelectuales, quienes tienen en común ser pecadores, sin embargo, ante la belleza, virtud y bondad de la Virgen el mal retrocede. De esta manera la Virgen María es la protagonista, en quien reside la bondad absoluta y el resto de los personajes cumplen el rol antagónico.

En una primera lectura todo está muy claro: el fin pedagógico-religioso de resaltar y glorificar la figura de María y conmover al oyente o lector con el fin de que se arrepienta y busque la gracia de Dios a través de la Virgen se cumple a cabalidad.

Además de los milagros que ejecuta María a favor de los pecadores, lo que la convierte en una heroína literaria, existe todo un apoyo lírico en torno a esta figura y, así, el aprecio estético por ella es indiscutible.

Con el objeto de conocer la fuerza antagónica que le permite a María erigirse como la protagonista del bien, revisaremos la trayectoria de los personajes de cada milagro a través del siguiente cuadro esquemático que presenta al personaje, su conflicto y la resolución de tal conflicto: 


\section{Cuadro 3}

\section{Esquematización de Los Milagros de Berceo}

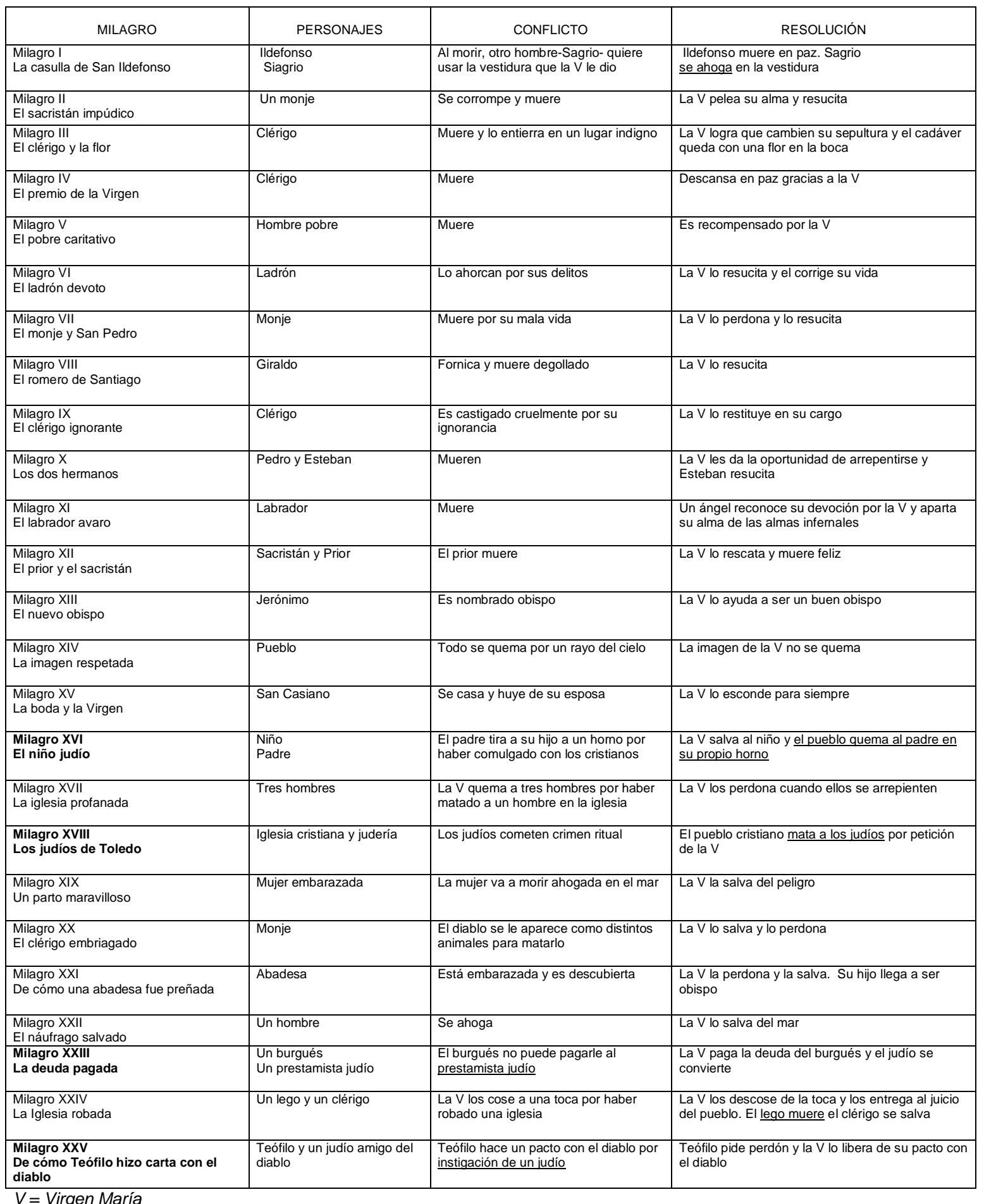


Se observa en este esquema que el resultado inicial de la acción humana en la mayoría de los casos es la muerte; sin embargo la Virgen intercede y la situación final cambia en beneficio del personaje afligido. Sucede esto en casi la totalidad de los milagros, pero no en todos. Si observamos atentamente los milagros en que el personaje/pecador recibe el favor de la Virgen notamos una constante: la devoción.

Ejemplos:

"De un clérigo leemos que era de sesos ido, y en los vicios del siglo fieramente embebido; pero aunque era loco tenía un buen sentido: amaba a la Gloriosa de corazón cumplido"14

"Érase en una tierra un hombre labrador que usaba de la reja más que de otra labor; más amaba la tierra que no a su Criador, y de muchas maneras era revolvedor.

Hacía una enemiga bien sucia de verdad: cambiaba los mojones para ganar heredad; hacía en todas formas tuertos y falsedad, tenía mal testimonio entre su vecindad.

Aunque malo, quería bien a Santa María, oía sus milagros, muy bien los acogía; saludábala siempre, decíale cada día: "Ave gratia plena que pariste al Mesías"15

Este tipo de presentación de los personajes es recurrente a lo largo de la obra. Los pecadores son devotos de María, por lo que ella perdona sus faltas e intercede milagrosamente salvándolos, inclusive, de la propia muerte.

De un total de veinticinco milagros sólo en cuatro la Virgen no perdona y se produce la muerte del personaje; tal ocurre en los milagros: I "La casulla de San Ildefonso", XVI "EI niño judío”, XVIII "Los judíos de Toledo" y XXIV "La Iglesia robada". Se observa con claridad que en dos de los milagros con final fatal los personajes son judíos, lo que nos inspira a atender con detenimiento el 
personaje judío que se presenta en esta obra de Berceo. Éstos aparecen en los milagros: XVI "El niño judío", XVIII “Los judíos de Toledo", XXIII "La deuda pagada” y XXV "De cómo Teófilo hizo carta con el diablo".

En primer lugar, los personajes judíos no cumplen con el requisito de los personajes perdonados: no son devotos de la Virgen. En segundo lugar, estos personajes se asemejan a la descripción del diablo.

Ejemplos:

En referencia al padre del niño judío que se convierte al catolicismo, Milagro XVI:

"Pesóle de esto tanto al malaventurado como si lo tuviera o muerto o degollado: no sabía con ira qué hacer el endiablado, hacía figuras malas como un endemoniado

Tenía dentro de su casa este perro traidor Un horno grande y fiero que daba gran pavor; Y lo hizo encender el loco pecador De manera que echaba soberano calor"

En referencia al judío que aconseja a Teófilo, Milagro XXV:

"Donde moraba Teófilo, en esa obispalía, había allí un judío en esa judería: sabía él cosa mala de toda alevosía, que con la hueste antigua tenía su cofradía

Era un falso truhán lleno de malos vicios, Sabía encantamientos y otros maleficios, Hacía el malo cercos y otros artificios, Beelzebub lo guiaba en todos sus oficios.

En dar consejos malos era muy sabedor, Mataba muchas almas este falso traidor: Como era vasallo de pésimo señor, Si aquél mal le mandaba, él hacíalo peor"

La Virgen transforma la maldad del hombre en bondad, así, a los malos los hace buenos, sin embargo la razón de esto es que los hombres sienten devoción por ella, comparten la fe católica. En el caso de los personajes judíos no es así, no hay perdón porque no hay devoción. En los 
milagros XVI y XXIII se produce la conversión judía y sólo en estos casos el perdón de la Virgen actúa a favor de estos personajes.

Tenemos 4 milagros específicos de judíos, veamos con mayor detención:

Cuadro 4

Milagros con personajes judíos

\begin{tabular}{|c|c|c|c|}
\hline MILAGRO & PERSONAJES & CONFLICTO & RESOLUCIÓN \\
\hline $\begin{array}{c}\text { Milagro XVI } \\
\text { El niño judío }\end{array}$ & $\begin{array}{c}\text { Niño judío } \\
\text { Padre judío }\end{array}$ & $\begin{array}{c}\text { El padre tira a su hijo a un } \\
\text { horno por haber comulgado } \\
\text { con los cristianos }\end{array}$ & $\begin{array}{c}\text { La Virgen salva al niño que se } \\
\text { convierte al cristianismo y el pueblo } \\
\text { quema al padre en su propio horno }\end{array}$ \\
\hline $\begin{array}{c}\text { Los judíos de Toledo } \\
\text { Milagro XVIII }\end{array}$ & $\begin{array}{c}\text { Iglesia cristiana y } \\
\text { judería }\end{array}$ & $\begin{array}{c}\text { Los judíos cometen crimen } \\
\text { ritual }\end{array}$ & $\begin{array}{c}\text { El pueblo cristiano mata a los judíos } \\
\text { por petición de la Virgen }\end{array}$ \\
\hline $\begin{array}{c}\text { La deuda pagada } \\
\text { Milagro XXV }\end{array}$ & $\begin{array}{c}\text { Un burgués } \\
\text { De prestamista judío }\end{array}$ & $\begin{array}{c}\text { El burgués no puede pagarle } \\
\text { al prestamista judío }\end{array}$ & $\begin{array}{c}\text { La Virgen paga la deuda del burgués } \\
\text { y el judío se convierte }\end{array}$ \\
\hline $\begin{array}{c}\text { con el diablo } \\
\text { amigo del diablo }\end{array}$ & $\begin{array}{c}\text { Teófilo hace un pacto con el } \\
\text { diablo por instigación de un } \\
\text { judío }\end{array}$ & $\begin{array}{c}\text { Teófilo pide perdón y la Virgen lo } \\
\text { libera de su pacto con el diablo }\end{array}$ \\
\hline
\end{tabular}

En todos los casos la Virgen es la que cumple el ROL protagónico y los personajes judíos el ROL ANTAGÓNICO. Los personajes en cuestión tienen APARICIÓN INDIRECTA en todos los casos, pues es el relator que cuenta la historia es quien los presenta, ellos no tienen voz.

En los Milagros XVI, XXIII y XXV el personaje es de NÚMERO UNITARIO y GÉNERO MASCULINO. Podemos observar que en estos Milagros, si bien los personajes son unitarios, la referencia a ellos es con la nominación genérica de "judío", de alguna manera este concepto encuentra eco en el Milagro XVIII donde el personaje es de NÚMERO COLECTIVO y GÉNERO MASCULINO. Al término de la lectura de la totalidad de los milagros el antagonista indiscutible de la Virgen es el colectivo judío.

Es posible construir una rica DESCRIPCIÓN SICOLÓGICA PLANA de los personajes judíos que nos presenta Berceo. Como ya se observó en los Milagros XVI y XXV la adjetivación de estos personajes se construye en torno a la maldad con conceptos como: malaventurado, 
endiablado, endemoniado, perro traidor, pecador, etc. Esta conceptualización continúa a lo largo de Ios Milagros XVI, XVIII, XXIII y XXV.

La constante maldad de los judíos los fija como personajes de DESARROLLO ESTÁTICO, todos tienen mal principio y mal fin, con excepción de los que se convierten. No obstante, esta maldad ayuda a destacar la bondad de la Virgen como protagonista del texto.

El texto de Gonzalo de Berceo es fundamental para el s.XIII, de hecho recoge la tradición de los exempla ${ }^{16}$ que consistía en relatos de la vida cotidiana que eran utilizados para introducir una verdad teológica en el sermón; consiguientemente, los judíos y los moros fueron los antagonistas recurrentes de estos relatos. Al respecto Jacques Le Goff ${ }^{17}$ recoge varios exempla de personajes judíos, analizando la colección Alphabetum Narrationum, compilada a comienzos del siglo XIV. Le Goff dice en su análisis de los exempla que los personajes judíos no son protagónicos, los protagonistas son cristianos y en los exempla los judíos tienen relevancia en la medida que se convierten al cristianismo. El rol de los personajes judíos es mostrar el camino equivocado por donde no se debe transitar.

Más adelante, Alfonso X recoge el exemplum y los Milagros de Berceo para nutrir sus "Cantigas de Santa María"18, que son, básicamente lo mismo ya visto, más plástica y música. Un buen ejemplo del continuum temático entre el exemplum, "Los Milagros de Nuestra Señora" y "Las Cantigas de Santa María" es la historia del niñito judío que se convierte ante la belleza de la Virgen y ésta lo salva del fuego cuando su padre lo echa a un horno hirviendo al enterarse de su conversión. Revisemos los textos: 
Texto 1: exemplum

$$
\text { Exemplum } \mathrm{CC}^{19}
$$

María etiam infidelibus adjuvat et sucurril

La Virgen María ayuda á los xpianos

E aun á los infieles malos é paganos

En la cibdad de Berri, el anno del Sennor de quinientos é vente é siete annos, acaesció que el día de Pascua, comulgando los xpianos, un mozo judio fué en vuelta de los mozos xpianos, é llegó al altar é tomó el cuerpo de Dios. É tornándose para su casa preguntóle su padre dónde venie; él dijo que fuera á la iglesia con los mozos con que iba á las escuelas, é que comulgara con ellos. É el padre con gran sanna arrebatólo é lanzólo en un forno candente que estaba allí, é luego la imágen de la Vírgen que habie visto sobre el altar, le apareció allí é lo libró del fuego. É á las voces de la madre del mozo ayuntáronse muchos judíos, é vieron el mozo en el fuego sin lision é sin danno, é sacáronlodende, é preguntáronle cómmo escapara, é díjoles que una duenna muy honrada que estaba sobre el altar le librara é le quitara todo el fuego. Estonce los xpianos, entendiendo que era la imágen de la Vírgen María, tomaron al padre del mozo, é lanzáronlo en el forno, é luego fué quemado.

Texto 2: milagro

Milagro XVI EL NIÑO JUDIO ${ }^{20}$

Fue en Bourges, una villa que se halla en tierra extraña en donde sucedió tan prodigiosa hazaña

de fuerte resonancia en Francia y Alemania, que merece contarse. Es verdad que no engaña.

Fue escrito este milagro por un monje sincero del claustro San Miguel, del que era personero, y que por ese tiempo actuaba de hospedero.

Era su nombre Pedro: De eso estoy bien certero.

En la misma ciudad -porque era menesterun clérigo atendía una escuela de leer y cantar, para quienes deseaban aprender, hijos de buena gente y de mayor valer.

Un niñito judío, natural del lugar,

para unirse a otros niños con el fin de jugar, venía a aquella escuela además de estudiar, acogido por todos también a conversar.

El domingo de Pascua, a la hora temprana en que recibe Cristo la población cristiana, de comulgar sintió él también mucha gana. Comulgó con los otros el cordero sin lana.

Mientras que se encontraba en esa coyuntura, el muchacho judío miró arriba, y a esa altura, encima del altar, vio la hermosa figura

de una bella señora con una creatura.

Vio que la hermosa dama que en ese sitio estaba era la que a los grandes y chicos comulgaba, y se sintió feliz. Cuanto más la miraba, de su gran hermosura mucho más se prendaba. 
Salióse de la Iglesia feliz, reconfortado, y regresó a su casa como estaba habituado. Lo amenazó su padre por haberse atrasado, por lo que merecía que fuera castigado.

"Padre -le dijo el niño- no he de negaros nada, pues con los cristianillos me fui de madrugada, y con ellos oí una misa cantada,

y comulgué con ellos de la hostia sagrada"

Al oír esto, el padre, el malaventurado, sintió como si su hijo se hubiese degollado. De ira, no sabía qué hacer el endiablado hasta desfigurarse como un endemoniado.

En su casa tenía ese perro traidor un gran horno que a todos producía pavor, el que lo hizo encender el loco pecador de modo que expidiera espantoso calor.

Tomó enseguida al niño el falso descreído, y así, tal como estaba, con calzado y vestido, lo arrojó en aquel fuego fieramente encendido. ¡Maldito el que así trata a su hijo querido!

Dio la madre -espantada- voces despavoridas dañando sus mejillas con profundas heridas frente a la multitud de gentes reunidas, que viendo aquel horror estaban aturdidas.

Pero el fuego, aunque bravo, tuvo comedimiento, $y$ al niño trató bien el terrible elemento, que en el horno se hallaba muy tranquilo y contento. Dios fue el maravilloso autor de este portento.

Mientras estuvo el niño en el horno, su faz era la del que en brazos maternos está en paz. Para él, ese fuego sólo era otro rapaz. La Gloriosa le daba compañía y solaz.

Salió el niño del fuego, intacto, sin lesión, sin sufrir más calor que el usual y en sazón, sin quemadura alguna y sin tribulación, pues Dios había puesto en él su bendición. Todos le preguntaron -judíos y cristianoscómo pudo vencer fuegos tan soberanos cuando no manejaba ni sus pies ni sus manos, y quién pudo dejarle todos sus miembros sanos.

El niño respondió con palabra excitada:

"La señora que estaba en la silla dorada con su hijo en los brazos sobre el altar posada, ella me defendió y no me pasó nada."

Comprendieron entonces que la señora ésta era Santa María, siempre a defensa presta. Entonáronle laudes. Le hicieron rica fiesta y en su honor escribieron el milagro de la Gesta.

Tomaron al judío, al falso y desleal que a su pequeño hijo hiciera tanto mal; le ligaron las manos con un fuerte dogal y lo echaron al fuego de su horno infernal.

Menos demoraría contar unos "pepiones" que lo que demoró en convertirlo en carbones. 
No decían por su alma si salmos ni oraciones, sino que mil injurias y otras mil maldiciones.

Decían mil maleficios y hacían mala ofrenda, y en vez de PATER NOSTER: "Quien tal hizo, tal prenda, que de su compañía el Señor nos defienda y que le dé al Demonio su fortuna y hacienda".

Así es Santa María, la de la gracia plena, capaz de darnos premios como de darnos pena: a los buenos, el trigo; a los malos, la avena.

Los unos van en la Gloria; los otros, en cadena.

Quien le presta servicio gana buenaventura; quien no la sirve a Ella, nació con desventura. Estos ganan rencor; aquellos, su ternura. Los buenos y los malos revelan su factura.

Quienes la despreciaron y nunca la sirvieron, ganaron sus favores apenas lo pidieron. Jamás repudió Ella a quienes la quisieron, ni dio réplica airada a los que mal le hicieron.

Para probar lo dicho tal como lo creemos, escuchad otro ejemplo de aquellos que leemos. Mientras más los contemos, mejor lo apreciaremos. De buscarle pesares aún más nos aguardaremos.

\section{Texto 3: Cantiga}

Cantiga IV ${ }^{21}$

Esta é como Santa María guardou so fillo do judeu que non ardesse, que seu padre deitára no forno.

\begin{abstract}
A Madre do que liurou dos leoes Danïel, essa do fogo guardou un menynno d' Irrael.

En Beorges un judeu ouue, que fazer sabía vidro, et un fillo seu (ca él én máis no auía, per quant' end' aprendí eu), ontr' os crischaos liýa na escol', e era greu a seu padre Samüel.

A Madre do que liurou dos leoes Danïel..

O menynno o mellor leeu que leer podía, et d' aprender gran sabor auue de quanto oýa; et por esto tal amor con esses moços collía con que era leedor, que ýa en seu tropel.
\end{abstract}

A Madre do que liurou dos leoes Danïel...

Porén uos quero contar o que II' aueo un dia de Pascoa, que foi entrar na eýgreia, ú uija o abad' ant' o altar et aos moços dand' ýa Ostïas de comungar et vynn' en un cález bel.

A Madre do que liurou dos leoes Danïl...

O judeucynno prazer ouue, ca lle parecía que Ostïas a comer lles daua Santa María que uija resprandecer en o altar ú sija, et en os braços teer seu Fillo Hemanuel.

A Madre do que liurou dos leoes Danïel... 
Qvand' o moç' esta uison uyú, tan muito lle prazía, que por fillar seu quinnon, ant' os outros se metía;

Santa María enton

a mao lle porregía,

et deu-lle tal comuyon,

que fois máis doce ca mel.

A Madre do que liurou dos leoes Danïel...
Poil-a comuyon fillou, logo d'alí se partía, et en cass' seu padr' entrou como xe fazer soýa; et ele lle preguntou qué fezera. El dizía: - A Dona me comungou que uí so o chapitel.-

A Madre do que liurou dos leoes Danïel...

Versión moderna:

Un hijo del judío Samuel, fabricante de vidrio en Bourges, se juntaba con otros muchachos en la escuela cristiana. Allí aprendió a leer, y cobró tal afición a cuanto oía y veía, que entró un día de Pascua en la iglesia cuando comulgaban sus compañeros. parecióle que daba las hostias la Virgen misma que estaba en el altar; e irremisiblemente arrastrado por aquella seductora visión, se acercó entre los demás al altar, y Santa María se dignó darle la sagrada comunión. Vuelto a su casa, refirió a su padre lo ocurrido. El padre, fuera de sí, cogió al niño y lo arrojó en el horno encendido. Raquel, madre del niño, juzgándole abrasado por las llamas, salió desolada a la calle, y a sus dolorosos clamores, acudieron gentes, las cuales con júbilo sacaron ileso al niño. Recibió éste el bautismo. La madre se hizo también cristiana. Fué castigado con la muerte el padre desnaturalizado.

Los tres textos expuestos evidencian, por una parte, que "la historia del niño judío" es de conocimiento popular pues los exempla eran relatados en las iglesias para los feligreses. Los milagros eran declamados también ante un populoso público y las cantigas se cantaban y bailaban en la corte del reino. Por otra parte, "la historia del niño judío" aun cuando encuentra distintas formas de expresión, mantiene la crudeza de su contenido: la maldad del judío es decididamente radical contrapuesta con la bondad de la Virgen. 


\title{
2.1.4. La Danza de la Muerte ${ }^{22}$
}

La Danza de la muerte (fines del siglo XIV) más que una obra particular de España Medieval, es un lei motiv recurrente de la época en períodos de hambruna, pestes y catástrofes naturales. La Iglesia enfrentaba a sus fieles contra la muerte porque era una realidad cotidiana, consecuentemente, era necesario prepararse para partir en paz.

El texto es una invitación del personaje MUERTE a acompañarla eternamente:

\begin{abstract}
"Aqui comiença la dança general, en la qual tracta como la Muerte avisa a todas las criaturas que paren mientes en la breviedad de su vida e que della mayor cabdal non sea fecho que ella meresce. E asimesmo les dize e requiere que vean e oyan bien lo que los sabios pedricadores les dizen e amonestan de cada dia, dandoles bueno e sano consejo que pugnien en fazer buenas obras porque hayan complido perdon de sus pecados. E luego siguiente mostrando por espiriencia lo que dize, llama e requiere a todos los estados del mundo que vengan de su buen grado o contra su voluntad."
\end{abstract}

Desfilan en esta obra un gran número de personajes representativos de cada segmento de la sociedad (el predicador, el padre santo, el emperador, el cardenal, el rey, el duque, el arzobispo, el condestable, el obispo, el caballero, el abad, el escudero, el dean, el mercader, el arcediano, el abogado, el canónigo, el físico, el cura, el labrador, el monje, el usurero, el fraile, el portero, el ermitaño, el contador, el diacono, el recaudador, el subdiácono, el sacristán, el rabí, el alfaquí, el santero), inclusive se invita a quienes no han sido nombrados:

\begin{abstract}
"A todos los que aqui non he nombrado de qualquier ley e estado o condicion, les mando que vengan muy toste priado" a entrar en mi dança sin escusacion"
\end{abstract}

En la Danza se muestran personajes recurrentes de la cotidianeidad, entre ellos un rabí, guía religioso de la comunidad judía. Junto al rabí aparecen otros líderes religiosos, especialmente católicos, a quienes se les critica por el exceso de atención a los placeres de la carne; en cambio, al rabí se le critica su error teológico. Veamos la relación e la Muerte con el Sacristán, el Rabí y el Alfaquí: 


\section{EL SACRISTAN:}

Muerte, yo te ruego que hayas piadad de mi que so moço de pocos dias, non conosci a Dios en mi moçedad nin quise tomar nin siguir sus vias.

Fia de mi, amiga, como de otros fias, por que satisfaga del mal que he fecho, a ti non se pierde jamas tu derecho, ca yo ire si tu por mi envias.

\section{LA MUERTE:}

Don sacristanejo de mala picaña, ya non tenes tiempo de saltar paredes nin de andar de noche con los de la caña faziendo las obras que vos bien sabiedes. Andar a rondar vos ya non podredes, nin presentar joyas a vuestra señora, si bien vos quiere, quite vos agora. Venit vos, rabi, aca meldaredes.

\section{EL RABI:}

Oh Helohim e Dios de Abraham que prometistes la redempcion! Non se que me faga con tan grand afan, mandad me que dance, non entiendo el son. Non ha homne en el mundo de quantos hi son que pueda fuir de su mandamiento. Veladme, dayanes, que mi entendimiento se pierde del todo con grand aflicion.

\section{LA MUERTE:}

Don rabi barbudo que siempre estudiastes en el Talmud e en los sus doctores, e de la verdat jamas non curastes, por lo qual habredes penas e dolores. Llegad vos aca con los dançadores e diredes por canto vuestra baraha: dar vos han posada con rabi Aza. Venit, alfaqui, dexad los sabores. 


\title{
EL ALFAQUI:
}

\begin{abstract}
Si Alah me vala, es fuerte cosa esto que me mandas agora fazer; yo tengo mujer, discreta, graciosa, de que he gasajado e asaz plazer. Todo quanto tengo quiero perder, dexame con ella solamente estar, de que fuere viejo, manda me levar, e a ella con migo si a ti ploguier.
\end{abstract}

\section{LA MUERTE:}
Venit vos, amigo, dexad el zala ca el gameño pedricaredes, a los veinte e siete vuestro capella, nin vuestra camisa non la vestiredes. En Meca nin en Layda y non estaredes comiendo buñuelos en alegria:
busque otro alfaqui vuestra moreria.
Pasad vos, santero, vere que diredes.

El análisis del personaje RABí no podrá ser muy acabado por lo breve del texto, sin embargo, podemos decir que su ROL es SECUNDARIO, APARICIÓN DIRECTA E INDIRECTA, NÚMERO UNITARIO, GÉNERO MASCULINO. SU DESCRIPCIÓN FÍSICA solo dice relación con su aspecto "barbudo", la DESCRIPCIÓN SICOLÓGICA es PLANA y se organiza en torno a la religiosidad meticulosa y errada del rabí. EI DESARROLLO es ESTÁTICO.

La descripción del Rabí respecto a su disciplina de estudio de las Escrituras y el gran error de interpretación de las mismas ya la habíamos leído en "El Auto de los Reyes Magos" (Apartado 2.3.2.). Es posible, entonces, que la breve descripción sicológica que registramos en "La Danza de la Muerte" encuentre eco en los antecedentes literarios ya expuestos y de esta manera esta descripción se haga más sólida para los oyentes. 


\subsubsection{Los Baños de Argel $^{23}$}

Esta obra escrita por Miguel de Cervantes, fue creada a inicios del siglo XVII, más exactamente en 1615. La obra fue escrita en España, pero como su nombre lo dice está ambientada en Argel, hoy Argelia. Es interesante, el hecho de que Cervantes pasara cinco años (1575-1580) cautivo en ese lugar bajo el dominio moro, experiencia que necesariamente lo inspiró para escribir la obra. El drama, en tres jornadas, trata del romance de Zahara y Don Lope, en un contexto de cristianos cruelmente cautivos en manos de los enemigos moros. Algunos estudios dicen que esta obra es un reflejo de la homosexualidad de Cervantes $^{24}$, otros la consideran una crítica a la intolerancia religiosa ${ }^{25}$, otros una autobiografía del paso del autor por Los Baños de Argel.

Para nuestro estudio esta obra muestra la representación de un personaje judío en un contexto situacional en que su presencia es completamente insignificante en una primera lectura, sin embargo en un acercamiento profundo al texto es posible detectar que "el judío es al cristiano como el cristiano al moro", lo cual en la producción literaria de Miguel de Cervantes es ampliamente concordante con su tratamiento del tema judío ${ }^{26}$.

Los moros son el grupo que detenta el poder y mantiene cautivo a los cristianos en Argel, en esa situación encontramos a un sacristán cautivo que a pesar de su situación disminuida ejerce poder frente a un menor, en este caso, un judío. Los episodios en que aparece el judío no son relevantes en la trama amorosa central, ni en la lucha mora/cristiana, por lo cual es posible revisar los trozos sin grandes introducciones temáticas. Veamos la primera aparición que se produce en la Segunda Jornada de la obra: 
[Se encuentran conversando un moro, un sacristán y un viejo sobre la miseria del cautivo; el moro está maltratando al sacristán, en eso...]

Versión original

(Entra un JUDÍO.)

VIEJO

¿No es aquéste judío?

\section{SACRISTÁN}

Su copete lo muestra,

sus infames chinelas,

su rostro de mezquino y de pobrete.

Trae el turco en la corona

una guedeja sola

de peinados cabellos,

y el judío los trae sobre la frente;

el francés, tras la oreja;

y el español, acémila,

que es rendajo de todos,

le trae, ¡válame Dios!, en todo el cuerpo.

¡Hola, judío! Escucha.

JUDíO

¿Qué me quieres, cristiano?

\section{SACRISTÁN}

Que este barril te cargues,

y le lleves en casa de mi amo.

JUDÍO

Es sábado, y no puedo

hacer alguna cosa

que sea de trabajo;

no hay pensar que lo lleve, aunque me mates.

Deja venga mañana,

que, aunque domingo sea,

te llevaré docientos.

\section{SACRISTÁN}

Mañana huelgo yo, perro judío.

Cargaos, y no riñamos.

JUDíO

Aunque me mates, digo

que no quiero llevallo.

\section{SACRISTÁN}

¡Vive Dios, perro, que os arranque el hígado!

JUDÍO

¡Ay, ay, mísero y triste!

Por el Dío bendito,

que si hoy no fuera sábado,

que lo llevara. ¡Buen cristiano, basta!

VIEJO

A compasión me mueve.

¡Oh gente afeminada,

infame y para poco!

Por esta vez te ruego que le dejes.

\section{SACRISTÁN}

Por ti le dejo; vaya

el circunciso infame;

mas, si otra vez le encuentro,

ha de llevar un monte, si le llevo.

JUDÍO

Pies y manos te beso,

señor, y el Dío te pague

el bien que aquí me has hecho.

(Vase el JUDíO.)

VIEJO

La pena es ésta de aquel gran pecado.

Bien se cumple a la letra

la maldición eterna

que os echó el ya venido,

que vuestro error tan vanamente espera.

\section{SACRISTÁN}

Adiós, que ha mucho tiempo

que estoy contigo hablando,

$y$, aunque mi amo es noble,

temo no le avillane mi pereza.

(Toma su barril y vase.)

[Más adelante, en la misma Segunda Jornada, vuelven a encontrarse el sacristán y el judío]

(Sale el SACRISTÁN con una cazuela mojí, y tras él el JUDÍO.) 
JUDíO

Cristiano honrado, así el Dío

te vuelva a tu libre estado,

que me vuelvas lo que es mío.

\section{SACRISTÁN}

No quiero, judío honrado; no quiero, honrado judío.

\section{JUDío}

Hoy es sábado, y no tengo qué comer, y me mantengo de aqueso que guisé ayer.

SACRISTÁN

Vuelve a guisar de comer.

\section{JUDÍO}

No, que a mi ley contravengo.

\section{SACRISTÁN}

Rescátame esta cazuela, y en dártela no haré poco, porque el olor me consuela.

JUDÍO

No puedo en mucho ni en poco contratar.

\section{SACRISTÁN}

Pues llevaréla.

JUDÍO

No la lleves; ves aquí

lo que costó.

\section{SACRISTÁN}

Sea ansí,

que a los dos es de provecho. ¿Dó el dinero?

\section{JUDíO}

Aquí, en el pecho

lo tengo, jamargo de mí!

\section{SACRISTÁN}

Pues venga.

JUDíO

Sácalo tú,

que mi ley no me concede

el sacarlo.

\section{SACRISTÁN}

¡Bercebú

así te lleve cual puede, decendiente de Abacú!

Aquí tienes quince reales justos de plata y cabales.

JUDÍO

No contrates tú conmigo; conciértalo allá contigo.

\section{SACRISTÁN}

Di, cazuela: ¿cuánto vales? «Paréceme a mí que valgo cinco reales, y no más". ¡Mentís, a fe de hidalgo!

JUDÍO

¡Qué sobresaltos me das, cristiano!

\section{SACRISTÁN}

Pues hable el galgo.

¿Que no quieres alargarte?

Mas quiero crédito darte: tomadla, y andad con Dios.

JUDÍO

¿Los diez?

\section{SACRISTÁN}

Son por otras dos cazuelas que pienso hurtarte.

JUDÍO

¿Y pagaste adelantado?

\section{SACRISTÁN}

$Y$, aun si bien hago la cuenta, creo que voy engañado.

JUDÍO

¿Que hay Cielo que tal consienta?

\section{SACRISTÁN}

¿Que hay tan gustoso guisado?

No es carne de landrecillas,

ni de la que a las costillas

se pega el bayo que es trefe.

JuDíO

¡Haced, cielos, que me deje este ladrón de cosillas!

$$
\text { (Éntrase el JUDíO.) }
$$

\section{SACRISTÁN}

¿De cosillas? ¡Vive Dios, que os tengo de hurtar un niño antes de los meses dos; y aun si las uñas aliño...! ¡Dios me entiende! ¡Vámonos! (Éntrase.) 
Finalmente, el la Tercera Jornada, el sacristán y el judío vuelven a tener un encuentro pequeño en el cual se muestra al sacristán robándole un niño al judío para criarlo en la fe cristiana, el Rey le devuelve el niño al judío y termina el episodio.

Como ya lo dijimos, los episodios en que se representa al judío no son fundamentales en la secuencia de las tramas principales, son cuadros aislados, y la comprensión de ellos será más rica en relación al total, pero el total de la obra no los requiere necesariamente. Tenemos, entonces, que el personaje judío cumple un ROL SECUNDARIO, su aparición es DIRECTA e INDIRECTA, pues los otros personajes nos hablan de él y, a la vez, él revela aspectos de su ser a través de sus dichos. En relación a lo que los otros personajes dicen de él, podemos observar que los descalificativos son abundantes:

"Perro judío"

"!Oh gente afeminada, infame y para poco!"

"Circunciso infame"

"!Bercebú así te lleve cual puede, descendiente de Abacú!"

"puto judío"

"hideputa",

y otros

El judío, al igual que en "Los Milagros de Nuestra Señora" (Milagro XVI), es denominado como "perro", esta nominación también la reciben los moros en esta obra, y ambas situaciones están en boca del sacristán.

EI NÚMERO es UNITARIO, pues es "un judío"; no obstante, el fenómeno que sucede con el concepto "judío/judíos" en "Los Milagros de Nuestra Señora", vuelve a repetirse aquí. Veamos con atención algunos versos del personaje Viejo en relación al judío:

\footnotetext{
"A compasión me mueve.

¡Oh gente afeminada,

infame y para poco! "

...

"La pena es ésta de aquel gran pecado.

Bien se cumple a la letra

la maldición eterna

que os echó el ya venido,

que vuestro error tan vanamente espera."
} 
Estos versos no son referidos al individuo que discrepa con el sacristán, están dirigidos al grupo al que pertenece este individuo, es decir, los judíos. En la Tercera Jornada aparece un parlamento del judío que también hace referencia a su grupo de pertenencia:

[El judío se queja ante el Rey por los abusos del Sacristán]

"Este español, señor, es la rüina de nuestra judería; no hay en ella cosa alguna segura de sus uñas."

Por todo lo anterior, EI NÚMERO si bien es UNITARIO, tiene matices de COLECTIVO. EI GÉNERO ES MASCULINO. En cuanto a la DESCRIPCIÓN, podemos apreciar una interesante DESCRIPCIÓN FÍSICA, expuesta en cuanto entra el judío a la escena:

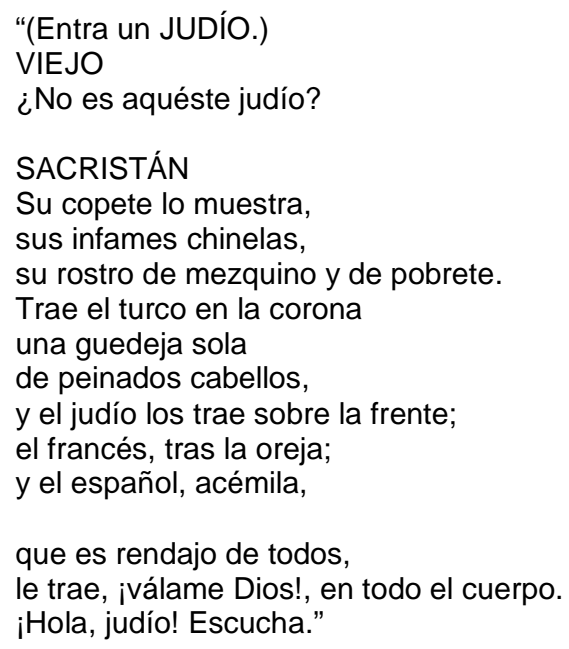

Estos versos indican una presencia física tipo, es decir general e igual para cualquier individuo del "grupo judío". No tenemos antecedentes de una descripción KINÉSICA, y la DESCRIPCIÓN SICOLÓGICA es PLANA, ya que el judío se muestra fuertemente fiel a sus costumbres religiosas, y servil ante los demás. EI DESARROLLO es ESTÁTICO.

Volvemos a encontrarnos en esta obra, como en "El auto de los reyes magos" y "La danza de la muerte", la terca observancia de las costumbres religiosas del judío que sobrepasan los límites del sentido común y hacen de estas prácticas un ritual que cae en lo ridículo del sin sentido. 


\subsubsection{Las paces de los reyes y la judía de Toledo ${ }^{27}$}

Esta obra, cuya primera edición data de 1617, fue escrita por el gran dramaturgo Lope Félix de Vega Carpio. Se compone de tres actos y su temática gira en torno al amor adúltero del rey Alfonso VIII con una judía, lo cual provoca importantes fracasos militares de los españoles frente a los moros.

El Primer Acto trata de la infancia de Alfonso VIII y su ascensión al reino. Ya en el Segundo Acto tenemos a Alfonso adulto, desposado con Leonor de Inglaterra. El reino está en paz y en alegría. La primera aparición de personajes judíos ocurre en la escena III del Segundo Acto, donde dos judías hablan de la pareja de reyes de España: 
Versión original

ACTO SEGUNDO Escena III

(Huerta del Rey a la orilla del Tajo.)RAQUEL, SIBILA.

RAQUEL

¿Pareciote bien Leonor?

SIBILA

Para hermosura extranjera

no pienso yo que pudiera,

Raquel, parecer mejor.

RAQUEL

$¿$ Es posible que te agrada

aquella nieve del Norte?

¿Qué cosa habrá que reporte,

con una hermosura helada,

el gusto de quien la mira?

¡Oh talle! ¡Oh brío español!

No pica al nacer el sol,

ni al tiempo que se retira;

al mediodía parece

que tiene fuerza mayor.

En España vive amor;

su brío y gusto merece

que reine Venus en ella.

La Chipre que celebró

la antigüedad, pienso yo

que llevó hermosuras della.

Yo, Sibila, aunque no soy

cristiana, soy española;

que basta esta gracia sola.

SIBILA

En tu pensamiento estoy,

aunque sé que no tenemos

las hebreas de nación

de briosas opinión.

RAQUEL

Es porque no la queremos.

Como vemos los cristianos

huir de la sangre nuestra,

¿de qué sirve darles muestra

del brío en lengua ni en manos?-

Luego que pasar la vi

a su iglesia con su esposo,

aunque era su rostro hermoso,

su condición presumí.

Yo te digo que aunque pruebe

Alfonso a tenerla amor,

que nunca de su Leonor

beba los gustos sin nieve.

SIBILA

No se te ha echado de ver,

Raquel, el haberte helado

de haber a Leonor mirado

mas te debió de encender

pues desde allí te has venido

a bañar al Tajo luego.

RAQUEL

¿No puede haber algún fuego

en esa nieve escondido?
SIBILA

¡Fuego! ¿Cómo?

RAQUEL

¿No podía

lo que la reina me heló,

abrasarme Alfonso?

SIBILA

No,

pues daba en nieve tan fría;

que el sol, cuando reverbera

de nieve, no da calor.

RAQUEL

Alfonso, me debe amor.

SIBILA

Es rey.

RAQUEL

Aunque no lo fuera.

Considero yo entre mí

aquel brío de soldado

junto a un ángel tan helado...

SIBILA

¿Tú quieres bañarte?

RAQUEL

Sí.

SIBILA

Pues dejemos en su casa

los reyes.

RAQUEL

Esta arboleda,

por cuyas plantas tan leda

el agua del Tajo pasa

pienso que puede encubrirme.

SIBILA

No hay un ave que te vea.

RAQUEL

Como amor lince no sea,

nadie podrá descubrirme.

SIBILA

El amor dicen que es ciego.

RAQUEL

No para ver lo que ama.

SIBILA

Pues ¿qué?

RAQUEL

El honor, tiempo y fama

que pierde. Mira, te ruego,

no se escondan por ahí

los amantes de la hebrea

Susana, y como ella, sea.

SIBILA

Fía tu cuidado en mí.

RAQUEL

¡Ay Dios!

SIBILA

¿Qué fue el accidente?

RAQUEL

Pensé que el rey me miró...

- Y es que, como me agradó,

le tiene el alma presente.

(Éntranse en una arboleda.) 
A diferencia de los otros textos analizados, "Las Paces de los reyes" y "la judía de Toledo" presenta a los personajes judíos con más parlamentos; en esta escena vimos a dos hermanas criticando el amor entre los reyes, se desprende de sus dichos el orgullo por ser judías y españolas, y también una superioridad femenina frente a la reina.

En la siguiente escena se están bañando en el río Tajo y en ese momento llega el Rey con su mejor vasallo:

Escena IV

EL REY

Huélgome de tratar contigo a solas, por esta orilla donde el manso viento

encrespa al Tajo las corrientes olas, mi siempre recogido pensamiento. Aunque le traigo, Garcerán, conmigo,

no siempre le apercibo en lo que siento.

Su rostro un hombre trae siempre consigo,

y no le puede ver sin un espejo; y así, llaman espejo a un hombre amigo.

Mi pensamiento miro en tu consejo; que verle sin tu espejo es imposible, y por eso contigo me aconsejo. Yo pasé, conde, mocedad terrible, perseguido de propios y de extraños,

más que parece a tal edad posible. Vestí las armas sin tener diez años, saqué la espada a luz, cobré mi reino,

y el cielo me libró de tantos daños: caseme, amo a Leonor, contento reino.

Si no ensancho los reinos heredados,

¿qué dejaré a mis hijos?

GARCERÁN

Aquí cierra

la puerta amor, que abrieron tus pasados;

mas no te excusas de seguir la guerra,

porque la fe, señor, más se dilate y salga el moro de tu misma tierra. Las fronteras de Córdoba combate pues cuando ve que cuelgas las espuelas,

se calza el africano el acicate.

Él viene, si no vas; pues ¿qué recelas,

si el amor de tu esposa no te abrasa,

y en la defensa de tu amor te hielas?

¿¿Qué te diviertes?

REY

ven, pasa,

ansí te guarde, Garcerán, el cielo y aumente las grandezas de tu

$¿$ No ves en los cristales, vuelta en

hielo,

una ninfa del Tajo, que porfía

hacer del agua a todo el cuerpo un velo?

¿No ves del dulce Ovidio la poesía erdad en las riberas de Toledo,

como él en las de Arcadia la fingía? GARCERÁN

Que a los dos sienta y vea tengo

miedo.

No vi, por Dios, señor, tanta

hermosura.

Mirarla sin deseo apenas puedo.

REY

¿Cuál escultor jamás hizo figura de pario mármol tan perfeta y bella, ni la imaginación de nieve pura?

No sé qué pueda comparar con ella. GACERÁN

Ea, jseñor, señor!

REY

¿Llamas?

GARCERÁN

Sí llamo.

REY

Pues bien...

GARCERÁN

Parece que te vas tras ella.

REY

Ya se enjuga y se viste. ¡Oh verde

ramo!

Rayo te abrase, que le das la ropa. Desde el extremo al tronco te

disfamo.

GARCERÁN

¿Qué! ¿Quisieras roballa como a

Europa,

o que por esta selva se anduviera como el tiempo de Adán, el viento en popa?

Nunca tal de tus ojos presumiera.

Así miró David otra hermosura,

que estaba haciendo cristalina

esfera

las claras aguas de una fuente pura

que le costó después fuentes de

llanto.

¡Oh nuevo mal! ¡Oh extraña

desventura!

GARCERÁN

¿Qué tienes?, que me das notable

espanto en la mudanza que en tu rostro has hecho.

REY

No pensé que mi daño fuera tanto. GARCERÁN

¿Puede ser más, que emponzoñarte el pecho

aqueste basilisco con sus ojos?

REY

Mayor estrago, mayor mal

sospecho.

GARCERÁN

¿Estrago de tan fáciles antojos?

REY

¿No ves en los vestidos, que es

hebrea,

de que me pueden resultar enojos? GARCERÁN

Como sólo mirar con ellos sea,

no repares en eso; y si reparas, guárdate de emprender cosa tan fea.

REY

Garcerán, el servir tiene dos caras, verdad, y gusto del señor. Agora ponte en la de mi gusto.

GARCERÁN

¡Oh, cuántas raras

virtudes que hay en ti, señor,

desdora

tan feo error!

REY

Aún no me has entendido.

GARCERÁN

Mira, señor, que tu Leonor te adora. REY

Vístete, Garcerán, deste vestido ponte la cara de mi gusto, y calla. GARCERÁN

No te enojes, señor: perdón te pido. REY

Ya está vestida; di que quiero

hablalla.

GARCERÁN

Aquí tengo aquel paje que conoces; llamarele, y podrá tu amor contalla. REY ¡Qué graciosa locura!

GARCERÁN

No des voces.

Yo la hablaré, si aquí me esperas.

REY

Parte.

GARCERÁN

$Y$ no te enojes más, ansí la goces. REY

Al pie deste moral quiero esperarte. (Vase GARCERÁN.) 
Si bien en la tercera escena pudimos constatar la propia percepción que las judías, especialmente Raquel, tienen de ellas mismas, en la cuarta escena se establece de forma sólida la percepción que los españoles tienen de las judías. El rey Alfonso mira al río y sin saber quién es la persona que se baña se rinde ante su belleza. Por esta mujer incógnita refiere lo siguiente:

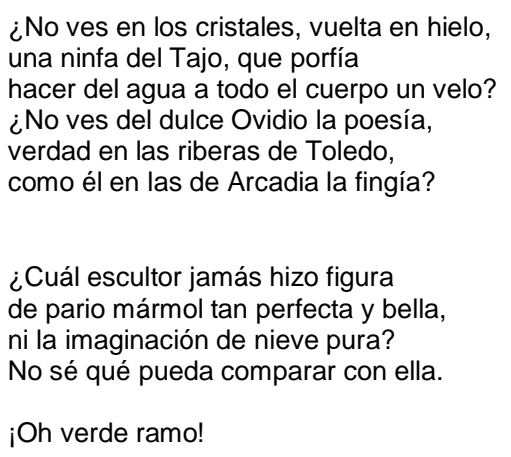

Sin embargo, cuando la desconocida se viste aparece su condición de judía, ante lo cual el rey exclama:

“¡Oh nuevo mal! ¡Oh extraña desventura! “

"No pensé que mi daño fuera tanto."

"Mayor estrago, mayor mal sospecho."

“¿No ves en los vestidos, que es hebrea, de que me pueden resultar enojos? "

Los dichos de Garcerán también son negativos respecto a la judía, y lo que inicialmente se veía como un aceptable romance del rey con la desconocida se transforma en una empresa tan fea, feo error.

Más adelante, en la séptima escena, el rey se encuentra con Belardo, un hombre cualquiera, a quien le pregunta por la mujer del río:

"REY

¿Habéis visto en la ribera deste río dos mujeres? BELARDO

Sí vi, y en extremo bellas; pero tienen una falta, si no me engaña la muestra: que pienso que son judías. 
REY

Llamadlas, buen hombre, hebreas.

(...)

REY

(Aparte) Miedo me ha puesto el villano.

Dime, amigo: ¿en esta huerta

entraron con gente, o solas?

BELARDO

¿Cuándo vistes gente destas

que fuese pobre jamás?

Un coche y gentil merienda

las trujo adonde las veis.

REY

¿Que es gente rica?

BELARDO

¿Pudiera ser pobre?

REY

Guárdeos el cielo.

BELARDO

$Y$ a vos, señor, os defienda

de dar en tan gran error;

porque si cristiana fuera,

ya tuviérades disculpa;

mas, en su ley, es bajeza...

¡Un hidalgo como vos!

(Vase)

REY

Parece que el cielo enseña

hasta los rudos villanos.

¡Oh amor, terrible es tu fuerza!

Entonces, no solo la opinión del rey y su vasallo es negativa sobre las judías, sino también la voz popular, lo que se deduce de los dichos de Belardo.

El amor que Raquel causa en el rey es tan fulminante que, finalmente, Alfonso se va con ella 7 años y descuida su reino, su esposa y su hijo. Ante esta situación la reina Leonor trama la muerte de Raquel e increpa a sus vasallos para que terminen con el mal que ha caído sobre España. En el Acto Tercero, podemos ver el gran parlamento de la reina, parte de él dice así.

\footnotetext{
"Alfonso, cuyas virtudes

el Bueno, cual veis, le nombran,

ya pierde el nombre que tuvo,

con una hazaña tan loca.

Siete años ha que encerrado

con aquella hebrea hermosa,

segunda Cava de España,

vive retirado a solas.

No se acuerda de sí mismo,

ni atiende ni acude a casa

de su reino, de su vida,

de su fama y de su honra.

Raquel reina, Raquel tiene
} 


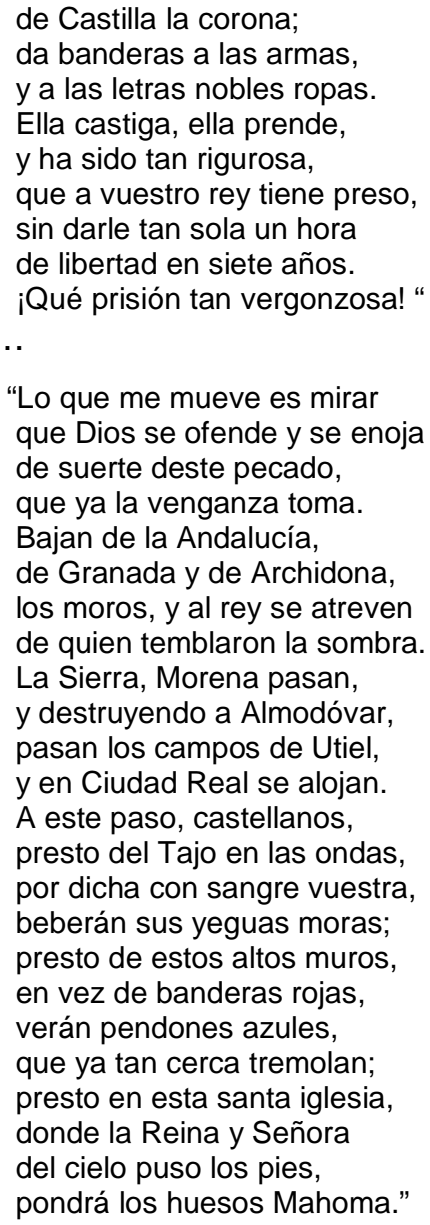

La reina en su discurso hace recaer toda la derrota de España frente a los moros en la judía Raquel, no en la lujuria de Alfonso ni en la debilidad militar española, y es tanto el convencimiento de la argumentación que sus vasallos acogen la petición de la reina y parten en busca de Raquel para matarla.

En la escena XIV del Tercer Acto tenemos la muerte de Raquel: 


\author{
Escena XIV \\ BELTRÁN, DON ILLÁN, y \\ después \\ DON BLASCO y otros; dichos. \\ BELTRÁN \\ Dentro.) Romped las puertas. \\ BELTRÁN \\ Huye, señora. \\ RAQUEL \\ No puedo. \\ D. ILLÁN \\ (Dentro.) Entrad, hidalgos, y \\ muera \\ la Circe que al rey cautiva, \\ y la hechicera Medea. \\ (Salen con las espadas \\ desnudas D. BLASCO, \\ BELTRÁN, D. ILLÁN y otros \\ CABALLEROS.) \\ RAQUEL \\ ¿Buscaisme a mí, caballeros? \\ D. BLASCO \\ Pues ¿quién quieres tú que sea \\ la que, siendo una mujer \\ tantas espadas merezca? \\ RAQUEL \\ La que fue más desdichada, \\ pienso que mejor dijeras. \\ D. ILLÁN \\ ¡Desdichada! ¿Por qué causa \\ por desdichada te cuentas? \\ $¿$ No has gozado un rey siete \\ años, \\ que ni su gente en la guerra, \\ ni su mujer en la paz
}

le han visto un hora siquiera?

REY

¡Qué buen gozo, si este fin

es todo el bien que me queda

de haber ese rey gozado!

¡Pluguiera al cielo que fuera

un labrador como aquél!

BELTRÁN

Suplícole no me meta,

en sus historias a mí.

RAQUEL

¡Oh amor! De cualquier manera

has de acabar en desdichas.

¡Malditas tus glorias sean!

BELTRÁN

¿Qué queréis, si no es posible

que otro fin más dulce tenga?

D. BLASCO

Caballeros, ¿qué aguardáis,

si en la muerte desta Elena

vuestro remedio consiste

y el de toda España?

(Hiérenla.)

¡Muera!

RAQUEL

Muero en la ley de mi Alfonso;

testigos los cielos sean.

Creo en Cristo, a Cristo adoro.

BELTRÁN

La ley de Cristo confiesa.

(Muere RAQUEL)

D. ILLÁN

Muera su hermana Sibila.

SIBILA

¿A mí? ¿Por qué?

ILLÁN

Porque sea

esta venganza famosa.

(Mata a SIBILA.)
BELTRÁN

Muertas en su estrado quedan.-

¿Quién eres tú?

BELARDO

El hortelano

soy yo, señor, desta huerta.

BELTRÁN

También éste ha de morir.

BELARDO

Es verdad, cuando Dios quiera; pero agora, ¿por qué causa?

BELTRÁN

Que cuanto esta casa encierra, se ha de pasar a cuchillo.

BELANDO

Oídme.

BELTRÁN

¿Qué?

BELANDO

Escuchad.

BELTRÁN

Abrevia.

BELANDO

Yo sé dónde está el tesoro,

plata, joyas y cadenas.

D. BLASCO

No le matéis.

D. ILLAN

Alto, pues.- Adónde está nos

enseña.

BELANDO

Echad todos por aquí.

BELTRÁN

Vamos.

BELANDO

(Aparte.) Si cojo la puerta, no me ha de alcanzar el Cid en su caballo Babieca. (Vanse.)

Al morir Raquel y Sibila el reino vuelve a su equilibrio inicial, los reyes hacen las paces y los moros comienzan a retroceder en la batalla.

Además de Raquel y Sibila, en la obra aparecen más personajes judíos, David y Leví, quienes no tienen un papel fundamental en el conflicto. Ellos y Sibila son el entorno judío de Raquel y nada más. Por esto nuestro análisis del personaje solo se centrará en Raquel.

Raquel cumple un ROL ANTAGÓNICO, su APARICIÓN es DIRECTA e INDIRECTA, si bien es un personaje de NÚMERO UNITARIO, contiene, como en otros personajes ya estudiados, el eco de su comunidad, pues su nombre es parte de la tradición. Incluso en la escena VII del Segundo Acto, el rey pide que se le diga hebrea en vez de judía para que su enamoramiento sea más aceptable. 
Evidentemente el concepto "judío" en este momento de la tradición literaria ya está con una carga semántica muy negativa.

En esta obra por primera vez tenemos personajes con nombres propios; "Rachel y Vidas" en el "Cantar del Mío Cid" más que nombres propios era una marca prestamista. Raquel es un nombre con historia dentro del judaísmo y también heredera de la pareja prestamista; en la escena VII del Segundo Acto el hombre de pueblo, Belardo, dice que la gente judía es rica como una característica esencial, lo que nos remite al episodio de las "Arcas de arena" del "Cantar del Mío Cid". Pero, además de ser nombrada Raquel y nominada como judía y hebrea, aparecen otros vocablos para hacer referencia a este personaje: mujer mal nacida, mujer sin fe, traidora, vil mujer, esclava Agar, hechicera, infame, Elena, hechicera Medea.

EI GÉNERO del personaje es FEMENINO. Por otro lado, tenemos como DESCRIPCIÓN FíSICA que es una mujer extraordinariamente hermosa y que viste a la usanza judía, como en el caso del judío de "Los Baños de Argel". La DESCRIPCIÓN SICOLÓGICA es PLANA, Raquel se siente superior a Leonor en su condición de amante, se sabe hermosa, y esas son sus características fundamentales; a pesar de que en el último momento de su vida se convierte al cristianismo, este proceso no se revela en un diálogo que nos permita obtener más información sicológica compleja del personaje.

EI DESARROLLO es DINÁMICO, pues comienza siendo una judía y termina como cristiana, cambio que permite la restitución del equilibrio en España.

Además de lo expuesto, podemos observar que Toledo vuelve a ser un lugar recurrente en la literatura que presenta personajes judíos, recordemos el milagro de Gonzalo de Berceo "Los judíos de Toledo", de esta manera se establece una red semántica de conceptos que se refuerzan entre sí; es decir que la segunda parte del título de la obra "La judía de Toledo" necesariamente es heredera del milagro de Berceo titulado de la misma manera en el siglo XIII. Esta herencia plantea a Raquel como un peligro para la comunidad, por lo cual debe ser destruida, al igual que los judíos del milagro. La diferencia en la obra de Lope de Vega radica en que Raquel se convierte al cristianismo a la hora de su muerte y esto permite un final feliz que concuerda con el equilibrio de 
reino. La conversión quita la tragedia de la muerte, consiguientemente, la muerte pasa a ser un paso a la eternidad cristiana.

\subsubsection{EL mayor monstruo del mundo ${ }^{28}$}

La obra fue escrita por Pedro Calderón de la Barca en el siglo XVII (1637), está ambientada en la época del Imperio romano, en la ciudad de Jerusalén y otras cercanías. La trama gira en torno a los celos y el poder. En esta obra el personaje judío no se presenta con la evidencia de las obras ya vistas; si la comparáramos con su coetánea "Las paces de los reyes" y "la judía de Toledo", nos parecería completamente discreta y dudaríamos de la pertinencia en considerarla parte del corpus que estamos revisando. Sin embargo, el centro de las disputas de amor y poder militar se centran en el personaje Mariene, quien no es descrita como judía con la abundancia vista en la obra de Lope de Vega, sino que solamente en un verso se explicita su condición judía. Veamos en la Jornada Primera, escena XIII, la forma en que el Tetrarca Herodes se refiere a Mariene:

"Tu eres bellísima hebrea,

La luz hermosa que sigo,

La beldad que sola adoro,

La imagen que sola admiro"

Todas las referencias a Mariene como personaje son positivas, sin embargo ella es el centro magnético del conflicto.

La obra, como la clásica tragedia griega, tiene un sino sobre un personaje que es Mariene, ella morirá en manos del mayor monstruo del mundo. Está casada con Herodes, quien quiere hacerla reina de Roma, y para esto debe vencer a Octavio, actual monarca.

En la Primera Jornada, escena primera, Mariene le cuenta a Herodes el destino que le ha descubierto un docto judío. Leamos parte del parlamento:

"Nunca pensé decirlo; pero escucha:

Un doctísimo hebreo

tiene Jerusalén, cuyo deseo

siempre ha sido, estudioso

apresurar al tiempo presuroso 
la edad, como si fuera

menester acordarle que corriera.

" Este pues vigilante,

en láminas leyendo de diamante

caracteres de estrellas,"

hoy los futuros contingentes dellas

a todos adelanta:

tanta es la fuerza de su estudio, tanta,

que es oráculo vivo

de todo ese cuaderno fugitivo,

que en círculos de nieve

un soplo inspira, y un aliento bebe.

Yo, que mujer nací (con esto digo

(que amiga de saber), docto testigo

le hice de tu fortuna y mi fortuna,

porque viendo que al orbe de la luna

hoy empinas la frente,

el futuro previne contingente.

Con el mío juzgó tu nacimiento,

y a los delirios de la suerte atento,

halló. .. Aquí el labio mío

torpe, muda la voz, el pecho frío,

se desmaya, se cansa y desfallece,

y aquí todo mi cuerpo se estremece.

Halló, en fin, que sería

trofeo injusto yo i qué tiranía!

de un monstruo el más cruel, horrible y fuerte

del mundo: halló también, que daría muerte

(¿ qué daño no se teme prevenido )

ese puñal, que ahora traes ceñido,

a lo que más en este mundo amares.

i Mira si tales penas, si pesares

tan grandes, es forzoso

que tenga mi discurso temeroso,

muerta la vida y vivo el sentimiento!

Pues infaustos los dos, con fin sangriento,

por ley de nuestros hados,

vivimos a desdichas destinados:

tú, porque ese puñal será homicida

de lo que más amares en tu vida;

y yo, siendo con llanto tan profundo,

trofeo del mayor monstruo del mundo."

El trágico destino relatado por la hebrea se complementa con las fuerzas políticas romanas, pues

Octaviano ocupa Jerusalén y en la ocupación descubre el retrato de Mariene, del cual queda completamente enamorado. Luego, Herodes es apresado y al ver el retrato de Mariene en manos de Octaviano cree que su esposa lo engaña, por lo que, finalmente, le da muerte.

Además de Mariene, aparecen otros personajes judíos: soldados y el docto que da el oráculo, sin embargo estos personajes no son relevantes porque no interfieren directamente en el conflicto. Por esta razón nuestro análisis se centra en Mariene; ella cumple el ROL PROTAGÓNICO en la 
obra, su APARICIÓN es DIRECTA, de todos los personajes judíos estudiados ella es la que posee mayores parlamentos, tanto en extensión como en problemáticas, el NÚMERO es UNITARIO y GÉNERO FEMENIMO. La DESCRIPCIÓN FíSICA se concentra en la belleza al igual que en el personaje Raquel de la obra de Lope de Vega y la DESCRIPCIÓN SICOLÓGICA es REDONDA, pues gracias a los parlamentos de Mariene accedemos a un personaje que expresa amor, miedo, culpa, tristeza y un gran conflicto interno desencadenado por el sino que recibe. El DESARROLLO es DINÁMICO, Mariene está inicialmente enamorada y confiada en su esposo, luego se siente acogida por Octaviano cuando sabe del plan de muerte que prepara Herodes y, finalmente, sus sentimientos por Herodes son de angustia y miedo.

\subsubsection{La rosa de pasión ${ }^{29}$}

Esta obra corresponde a una serie de leyendas publicadas por Gustavo Adolfo Bécquer en 1860 con el nombre de "Rimas y leyendas". Es un pequeño relato que cuenta el origen del nombre de una rosa: En Toledo hace mucho tiempo atrás, una hermosa hebrea que amaba a un cristiano y se convirtió al cristianismo fue asesinada horrorosamente en manos de su padre ya que él odiaba a los cristianos..

Como es posible observar, la temática es recurrente, ya tenemos las coordenadas básicas de esta historia en los exempla, en las cantigas de Alfonso X y en los milagros de Gonzalo de Berceo. ${ }^{30}$ Lo interesante en esta leyenda es la copiosa descripción de los personajes judíos: Daniel, el mal padre y Sara, la buena hebrea conversa. Estos personajes son contrapuestos física y sicológicamente, al punto de operar al interior del texto casi una didáctica de lo bueno y lo malo, donde lo malo es el judaísmo y lo bueno el cristianismo. De hecho esta leyenda se presenta al lector como una leyenda religiosa.

El narrador al inicio del relato presenta a Daniel de la siguiente forma: 
"En una de las callejas más oscuras y tortuosas de la ciudad imperial, (...), tenía hace muchos años su habitación raquítica, tenebrosa y miserable como su dueño, un judío llamado Daniel Leví. Era este judío rencoroso y vengativo, como todos los de su raza, pero más que ninguno engañador e hipócrita.

Dueño, según los rumores del vulgo, de una inmensa fortuna, veíasele, no obstante, todo el día acurrucado en el sombrío portal de su vivienda, componiendo y aderezando cadenillas de metal, cintos viejos o guarniciones rotas(...) Aborrecedor implacable de los cristianos y de cuanto a ellos pudiera pertenecer, jamás pasó junto a un caballero principal o un canónigo de la primada sin quitarse una y hasta diez veces el mugriento bonetillo que cubría su cabeza calva y amarillenta, ni acogió en su tenducho a uno de sus habituales parroquianos sin agobiarlo a fuerza de humildes salutaciones, acompañadas de aduladoras sonrisas.

La sonrisa de Daniel había llegado a hacerse proverbial en todo Toledo, y su mansedumbre, a prueba de las jugarretas más pesadas y las burlas y rechiflas de sus vecinos, no conocían límites.

Inútilmente los muchachos, para desesperarlo, tiraban piedras a su tugurio; en vano los pajecillos y hasta los hombres de armas del próximo palacio pretendían aburrirlo, llamándole con los nombres más injuriosos, o las viejas devotas de la feligresía se santiguaban al pasar por el umbral de su puerta, como si viesen al mismo Lucifer en persona.

Daniel sonreía eternamente, con una sonrisa extraña e indescriptible. Sus labios delgados y hundidos se dilataban a la sombra de su nariz desmesurada y corva como el pico de un aguilucho, y aunque de sus ojos pequeños, redondos y casi ocultos entre las espesas cejas, brotaba una chispa de mal reprimida cólera, seguía impasible golpeando con su martillito de hierro el yunque donde aderezaba las mil baratijas mohosas y, al parecer, sin aplicación alguna, de que se componía su tráfico."

La descripción de Daniel recoge todas las otras descripciones de los personajes masculinos estudiados en los sub capítulos anteriores; la riqueza y avaricia de Rachel y Vidas, la mansedumbre hipócrita del judío de los "Baños de Argel", la semejanza con Lucifer de los personajes judíos en "Los milagros de Nuestra Señora" de Berceo. Si ya en "Los Baños de Argel" teníamos una descripción física de la vestimenta del judío, en esta leyenda se nos presenta una corporal que opera como el reflejo de la miseria humana del personaje. Por otro lado, el narrador como contraposición de Daniel nos muestra a Sara, su hija: 
"Porque, en efecto, Sara era un prodigio de belleza. Tenía los ojos grandes y rodeados de un sombrío cerco de pestañas negras, en cuyo fondo brillaba el punto de luz de su ardiente pupila como una estrella en el cielo de una noche oscura. Sus labios, encendidos y rojos parecían recortados hábilmente de un paño de púrpura por las invisibles manos de un hada. Su tez era blanca, pálida y transparente como el alabastro de la estatua de un sepulcro. Contaba apenas dieciséis años, y ya se veía grabada en su rostro esa dulce tristeza de las inteligencias precoces, y ya hinchaban su seno y se escapaban de su boca esos suspiros que anuncian el vago despertar del deseo."

Sara es todo lo que no es Daniel, hermosa y buena. Ella también es heredera de los personajes judíos femeninos que hemos estudiado; Raquel y Mariene son hebreas hermosas como característica fundamental. Sara es llamada "hebrea" en el relato y no judía, lo mismo que ocurrió en los casos de Raquel y Mariene.

Tenemos, entonces un judío feo y malo y una hebrea hermosa y buena; ambas fuerzas se opondrán y lo feo y malo exterminará a lo hermoso y bueno.

Sara se ha enamorado de un cristiano y gracias a él tiene acceso al verdadero Dios. Daniel por su parte, se entera de lo sucedido y trama un plan para acabar con el cristiano, sin embargo, Sara interfiere con el plan de su padre y le confiesa su nueva fe, a lo que el padre responde con la muerte:

\footnotetext{
"-No; ya no lo soy [dice Sara]; he encontrado otro Padre, un Padre todo amor para los suyos, un Padre a quien vosotros clavasteis en una afrentosa cruz y que murió en ella por redimiros, abriéndonos para una eternidad las puertas del cielo. No; ya no soy vuestra hija, porque soy cristiana y me avergüenzo de mi origen.

Al oír estas palabras, pronunciadas con esa enérgica entereza que sólo pone el cielo en boca de los mártires, Daniel, ciego de furor, se arrojó sobre la hermosa hebrea y derribándola en tierra y asiéndola por los cabellos, la arrastró, como poseído de un espíritu infernal, hasta el pie de la cruz, que parecía abrir sus descarnados brazos para recibirla, exclamando al dirigirse a los que los rodeaban "
}

La reacción criminal y descontrolada de Daniel es absolutamente comparable a la del padre del niñito judío del Milagro XVI de Berceo, además las condiciones son las mismas: un hijo/a se convierte al cristianismo. Después del crimen, Daniel sigue su vida como siempre; años más tarde crece una rosa en el lugar donde fue asesinada Sara, una iglesia de Toledo. Junto a las recurrencias que hemos pesquisado en esta leyenda, "Toledo" aparece nuevamente como el lugar donde los judíos cometen actos criminales, desde el crimen ritual de la figura de Jesuscristo hasta el crimen de un judío que se convierte. Al igual que en el Milagro XVIII de Gonzalo de Berceo, "Los 
judíos de Toledo", en donde se describe el crimen ritual del cuerpo figurado de Jesús, aparece en la leyenda que estamos estudiando el mismo acontecimiento:

"Era noche de Viernes Santo, y los habitantes de Toledo, después de haber asistido a las tinieblas en su magnífica catedral, acababan de entregarse al sueño o referían al amor de la lumbre consejas parecidas a las del Cristo de la Luz, que, robado por unos judíos, dejó un rastro de sangre por el cual se descubrió el crimen, o la historia del Santo Niño de la Guardia, en quien los implacables enemigos de nuestra fe renovaron la cruel Pasión de Jesús. (...)

Sara, que en favor de la oscuridad había logrado llegar hasta el atrio de la iglesia, tuvo que hacer un esfuerzo para no arrojar un grito de horror al penetrar en su interior con la mirada. Al rojizo resplandor de una fogata que proyectaba las sombras de aquel círculo infernal en los muros del templo, había creído ver que algunos hacían esfuerzos por levantar en alto una pesada cruz, mientras otros tejían una corona con las ramas de los zarzales o afilaban sobre una piedra las puntas de enormes clavos de hierro. Una idea espantosa cruzó por su mente: recordó que a los de su raza los habían acusado más de una vez de misteriosos crímenes; recordó vagamente la aterradora historia del Niño Crucificado, que ella hasta entonces había creído una grosera calumnia inventada por el vulgo para apostrofar y zaherir a los hebreos."

Dentro del mismo texto literario aparece la referencia a la tradición literaria que estamos revisando, esto reafirma la red semántica que sostiene el conjunto de textos más allá de sus individualidades. El hecho de que Sara muera es, también, un hilo conector entre los personajes femeninos de nuestro corpus. Estas mujeres a pesar de ser hermosas y buenas, tienen un "sino": son hebreas y este concepto aunque no es fonéticamente igual, contiene toda la significación de la palabra "judío".

Por una parte, podemos decir que Sara cumple el ROL PROTAGÓNICO, que su APARICIÓN es DIRECTA e INDIRECTA, que tiene NÚMERO UNITARIO y GÉNERO FEMENINO, que presenta DESCRIPCIÓN FÍSICA y SICOLÓGICA REDONDA, ya revisada; y que su DESARROLLO es DINÁMICO.

Por otra parte, Daniel tiene un ROL ANTAGÓNICO, APARICIÓN INDIRECTA y DIRECTA, y si bien su NÚMERO es UNITARIO, sucede lo mismo que ocurre con otros personajes estudiados quienes aparecen como ejemplo de su raza. GÉNERO MASCULINO, DESCRIPCIÓN FÍSICA, KINÉSICA y SICOLÓGICA PLANA, DESARROLLO ESTÁTICO. En relación a la descripción kinésica de Daniel " todo el día acurrucado en el sombrío portal de su vivienda, componiendo y aderezando cadenillas (...) [con su] mal reprimida cólera, seguía impasible golpeando con su martillito" no dejamos de observar que esta postura acurrucada, encorvada, escondida, ya se nos había insinuado en 
personajes como Rachel y Vidas, el judío de "Los Baños de Argel” o el Rabí de "La Danza de la muerte", sin embargo no la podíamos verbalizar porque no contábamos con la clara descripción de un narrador como el de esta leyenda. La posición corporal descrita contiene un ocultamiento de algo y también una diligencia obsesiva de la tarea que se realiza, ya sea económica o religiosa.

\subsubsection{Gloria $^{31}$}

Benito Pérez Galdós escribe esta obra en 1876. Es una novela romántica que gira en torno a la alegría y desencanto del amor que padece Gloria. Ella es hija de una de las más aristocráticas familias de Ficóbriga, un pueblo español sumamente católico. Gloria es intelectualmente independiente, sin embargo la tradición católica es más fuerte en su mente que su ímpetu intelectual; no teniendo aprensiones sociales ni prejuicio alguno se enamora de un hombre extranjero que es acogido en su casa después de sufrir un naufragio. Lamentablemente para ella, este hombre resulta ser un judío, lo cual desencadena un tormentoso tránsito de la felicidad a la angustia. Gloria y el judío Daniel Morton tienen un hijo en circunstancias de tragedia y amor, pero, finalmente, la fuerza intolerante de ambas religiones los separa y Gloria muere enferma y Daniel muere de locura.

A diferencia de los textos estudiados, el personaje de Daniel Morton no hereda la penosa descripción dada a los judíos; si bien el nombre Daniel Morton nos evoca el nombre de Daniel Leví de "La rosa de pasión", no existe relación semántica alguna. Más aún, la descripción física de Morton es muy positiva. Encontramos en el Capítulo XVI "Ya llegó" de la primera parte de la novela, la siguiente descripción:

\footnotetext{
"Estaba tendido en la cama [Daniel Morton] y cubierto con gruesas mantas, a excepción de la cabeza. Sobre la cercana mesa había una luz. Gloria dio algunos pasos hacia el lecho y observando aquella cabeza, vio un rostro lívido y dolorido, con algunas manchas amoratadas como de golpes, entreabierta la boca, cerrados los ojos, ligeramente fruncido el ceño, húmedo el pelo. El perfil de aquella cara era perfecto, la frente hermosísima, entre oscuros cabellos desordenados. De las cejas rectas ligeramente arqueadas hacia la sien, partía la nariz aguileña, fina, intachable, como cortada por diestro cincel. Bigote castaño y barba del mismo color, un poco puntiaguda y ligeramente bifurcada en su extremidad, remataban dignamente un rostro que era de los más acabados que pueden imaginarse. Gloria, en aquel breve instante de observación, hizo un paralelo rápido entre la cabeza que tenía delante y la del Señor que estaba en la Abadía, dentro de la urna de cristal y cubierto con blanquísimas sabanas de fina holanda. (...)
} 
Junto a estos atributos físicos, comparables para Gloria al propio Jesucristo, Daniel es reconocido en el pueblo por su caballerosidad, amabilidad y bondad. La ciudad lo acoge y el amor entre él y Gloria comienza a crecer con fortaleza, pero él oculta su religión y cuando esto se descubre el hombre hermoso y bueno se transforma inmediatamente en un demonio. Leemos en el Capítulo XXXVII "Al fin se supo", de la primera parte:

\begin{abstract}
"Gloria arrodillándose delante de la imagen, tiró del brazo de Morton para que hiciera lo mismo. Daniel hundió la cabeza sobre el pecho. Nunca su rostro había estado más hermoso ni más patético. Pálido y grave, sus ojos azules se abatían con sombría tristeza, y vistas de perfil la elegante línea de su nariz y de su frente y la graciosa barba puntiaguda, su semejanza con el semblante carnal del Salvador del mundo era perfecta. -¿Por qué no me miras? -preguntó Gloria llena de desconsuelo.

-No puedo más -gritó Morton con súbito arranque-. Gloria, yo no soy cristiano.
\end{abstract}

-¿Qué dices? ¡Daniel, por Dios y la Virgen!

-Es preciso decírtelo al fin -añadió el extranjero hondamente conmovido-, y te lo diré. Gloria: yo no soy cristiano, yo soy judío.

-¡Jesús! ¡Padre y Redentor mío!

Estas palabras las pronunció Gloria con el espanto del que muere cosido a puñaladas; del que ve abrirse bajo sus pies la tierra y salir las llamas del infierno. Diciéndolas cayó sin sentido. Morton acudió hacia ella; arrodillándose tomola en brazos, procuró reanimarla con amorosas palabras; pero cuando ella abrió sus ojos y pudo ver junto a sí el característico rostro semítico que tanto había contribuido al cautiverio de su corazón, le rechazó severamente, diciendo:

-¡Impostor!... ¡Judas!... me has engañado.

-Te he ocultado mi religión -dijo Morton sombríamente-. Esa es mi culpa.

- ¿Por qué has ocultado tu religión? -dijo Gloria incorporándose vivamente.

Sus negros ojos echaban llamas.

-Por egoísmo, por temor a que no me amases -repuso Daniel con timidez y sumisión-. Yo no mentí; no hice más que callar: pero reconozco que callar fue gran falta.

- Infamia, infamia! No; es mentira... -dijo Gloria con desesperación-. Tú no puedes tener fe en esa doctrina.

-¡Quizás más que tú en la tuya!- repuso Morton.

-Mentira, mentira -exclamó la joven de rodillas en el suelo y retorciéndose los brazos-. Si fueses tú judío, es imposible que yo te hubiese amado. ¡Ah! parece que la lengua se me quema al decir esa palabra... Si el nombre solo de tu religión es una blasfemia... ¿Es posible, di, que no creas en Jesucristo, que no le ames?... Si esto es verdad, iqué horrible engaño, qué vida tan espantosa, qué muerte de las muertes! ¡Creer yo en ti de este modo, amarte, adorarte, y cuando pensaba vivir unida a ti para siempre, descubrirme, Dios mío, descubrirme este horrendo secreto!... ¿Por qué no escribiste en la frente tu infame creencia? ¿Por qué cuando me viste correr hacia ti, no me dijiste: «apártate que estoy maldito de Dios y de los hombres»?

- ¡A qué delirios te lleva tu fanatismo! -dijo Daniel contemplándola con expresión compasiva-. Acúsame por haberte ocultado la verdad; pero no injuries a mi desgraciada raza, ni participes de un odio vulgar indigno de ti.

-Si es verdad lo que me has dicho, ¿por qué no tuviste mala la apariencia, como tienes mala religión? ¿Por qué no fueron horribles tus palabras, tus acciones y tu persona como lo es tu creencia? ¡Impostor, cien veces impostor!

-Gloria, Gloria, amiga de mi vida, refrena tu lengua. Tus injurias me matan.

- ¿Por qué me has engañado, por qué consentiste que te quisiera, sabiendo que debíamos estar eternamente separados? -exclamó ella con el desvarío de quien va a perder la razón-. Dime, ¿por qué consentiste que te amara? 


\begin{abstract}
-Porque te amaba yo. Es verdad que procedí mal; pero también conocí mi falta, y viendo venir imponente y amenazador el conflicto religioso, de mí partió la idea de separarnos y te lo propuse. Mi pensamiento no podía ser más honrado.

-Sí; pero después volviste.

-Volví -repuso Morton confuso como el criminal-. Es verdad; no sé quién me trajo. Todo se ordenó de modo que yo volviese. Me trajo una especie de ola infernal, o quizás hálito divino. El hombre es juguete de las fuerzas de Dios que gobierna en el mundo.

-¡Dios! No tomes en tu boca ese nombre... Daniel, ¡cómo te has transformado a mis ojos! Tú no eres tú; no puedo decir fijamente si te amo o te aborrezco, y si cupiera esto en la mente humana, diría que al mismo tiempo te aborrezco y te amo.

Ocultando el rostro entre las manos, rompió a llorar sin consuelo.

-¡Y todo por un nombre, por una palabra! ¡Oh, qué iniquidad! -exclamó Morton con angustia-. Las palabras gobiernan al mundo, no las ideas. Dime, cuando me amaste, ¿por qué me amaste?

-Te amé porque me parecía que Dios te había puesto delante de mí; te amé por tu lenguaje, por tus acciones, por tu persona, por una dulce concordancia de tu alma con la mía... ¿Qué sé yo por qué?... Pero no... tú me estás engañando ahora... tú no puedes ser lo que dijiste, Daniel, porque tú has practicado la caridad.

-Nuestra ley nos dice: «Bienaventurado el que piensa en el pobre. En el día malo lo librará Jehová».

-Tú no puedes pertenecer a esa secta abominable -añadió Gloria asiéndose a su incredulidad como a un clavo ardiendo-. Aunque mil veces me lo jures, mil veces me negaré a creerlo... Si lo eres, iqué horrible disimulo el tuyo!

-He disimulado, sí. Esta es nuestra costumbre cuando viajamos por un país intolerante como el tuyo. Pero a ti debí decirte la verdad, lo conozco, lo confieso, declaro ante ti mi culpa, esperando perdón.

-Esto no puede perdonarse, no, de ningún modo -dijo Gloria con airada resolución. "
\end{abstract}

Se puede desprender del texto que la palabra judío encarna fealdad y maldad, Gloria protesta porque este judío es hermoso y caritativo, no hay correspondencia entre la tradición y el hombre real que tiene ante ella. No obstante el amor innegable que existe entre los personajes, será imposible saltar las trabas religiosas tradicionales y el final de ambos personajes, como ya lo dijimos, es la muerte.

Daniel Morton cumple el ROL PROTAGÓNICO junto a Gloria, APARICIÓN INDIRECTA Y DIRECTA, NÚMERO UNITARIO, GÉNERO MASCULINO, DESCRIPCIÓN FÍSICA, KINÉSICA y SICOLÓGICA REDONDA y DESARROLLO DINÁMICO. En relación al número unitario de este personaje, que sin duda lo es pues tiene aspectos completamente particulares respecto a los personajes ya vistos, su nombre "Daniel" es un elemento lingüístico de la red semántica que se ha establecido en relación al personaje judío; Daniel Morton y Daniel Leví son variantes del "judío" de la tradición literaria. Si bien Daniel Morton es un personaje que se cuestiona su proceder y es presentado por el narrador como un hombre bueno y hermoso, genera la muerte de la cristiana que se enamora de él. Gloria muere por el impacto del judío Daniel en su vida. Daniel Leví, por su 
parte, genera la muerte de su hija cristiana Sara. De esta manera, tenemos un personaje unitario que actualiza el personaje colectivo judío.

\subsection{Discusión general}

El estudio de la formación del estereotipo judío en España no es un tema nuevo. Muchos autores han escrito sobre las condiciones históricas que fueron construyendo una "imagen" específica, definida y negativa ${ }^{32}$ que se percibe muy fácilmente en los textos literarios. Sin embargo, literatura e historia no son lo mismo. El mundo literario es un constructo único, con sus propias reglas y redes se significación.

Nuestro análisis textual ha pretendido analizar las marcas lingüísticas que forman al personaje judío y, así, obtener una imagen hecha de palabras. Esta tarea es compleja por cuanto los textos analizados son de distintas épocas y géneros. Cada época tiene su propio sentido de estética y operará en el arte indiscutiblemente; los géneros literarios, por su parte, plantean a los personajes desde distintos ámbitos. A pesar de todas las dificultades que presenta un corpus heterogéneo, hemos podido aplicar un cuadro clasificatorio de aspectos del personaje en cada una de las obras $^{33}$. A partir de la clasificación realizada, podemos construir el siguiente cuadro resumen en el que es posible observar las constantes y variantes del personaje judío: 
Cuadro 3

RESUMEN ASPECTOS DEL PERSONAJE

\begin{tabular}{|c|c|c|c|c|c|c|c|c|c|c|c|c|}
\hline \multicolumn{3}{|c|}{$\begin{array}{l}\text { ASPECTOS DEL } \\
\text { PERSONAJES } \\
\text { OBRAS }\end{array}$} & $\begin{array}{l}\text { EI Cantar } \\
\text { del Mío } \\
\text { Cid }\end{array}$ & $\begin{array}{l}\text { El auto } \\
\text { de los } \\
\text { reyes } \\
\text { magos } \\
\text { S. XII }\end{array}$ & $\begin{array}{l}\text { Los } \\
\text { milagros } \\
\text { de } \\
\text { Nuestra } \\
\text { Señora } \\
\text { S. XIII }\end{array}$ & $\begin{array}{l}\text { La } \\
\text { danza } \\
\text { de la } \\
\text { muerte } \\
\text { S. XIV }\end{array}$ & $\begin{array}{l}\text { Los } \\
\text { baños } \\
\text { de } \\
\text { Argel } \\
\text { S. XVI }\end{array}$ & $\begin{array}{l}\text { Las } \\
\text { Paces de } \\
\text { los reyes } \\
\text { y la judía } \\
\text { de } \\
\text { Toledo } \\
\text { S. XVII }\end{array}$ & $\begin{array}{l}\text { El Mayor } \\
\text { monstruo } \\
\text { del mundo }\end{array}$ & \multicolumn{2}{|c|}{$\begin{array}{l}\text { La rosa de } \\
\text { Pasión }\end{array}$} & Gloria \\
\hline \multicolumn{3}{|c|}{ Personajes } & $\begin{array}{l}\text { Rachel y } \\
\text { Vidas }\end{array}$ & rabinos & judíos & rabí & judío & Raquel & Mariene & Sara & $\begin{array}{l}\text { Daniel } \\
\text { Leví }\end{array}$ & $\begin{array}{l}\text { Daniel } \\
\text { Darton }\end{array}$ \\
\hline \multirow{3}{*}{$\begin{array}{l}\text { R } \\
\text { O } \\
\text { L }\end{array}$} & \multicolumn{2}{|c|}{ PROTAGONISTA } & & & & & & & $\checkmark$ & 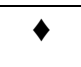 & & 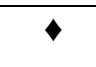 \\
\hline & \multicolumn{2}{|c|}{ ANTAGONISTA } & & & 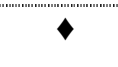 & & & $\bullet$ & & & $\bullet$ & \\
\hline & \multicolumn{2}{|c|}{ SECUNDARIO } & $\bullet$ & $\bullet$ & & $\bullet$ & $\bullet$ & & & & & \\
\hline \multirow{2}{*}{$\begin{array}{ll}\mathrm{A} \\
\mathrm{PA} \\
\mathrm{RI} \\
\mathrm{ClÓN}\end{array}$} & \multicolumn{2}{|c|}{ INDIRECTA } & $\downarrow$ & & $\diamond$ & $\downarrow$ & $\diamond$ & $\diamond$ & & $\downarrow$ & $\downarrow$ & $\diamond$ \\
\hline & \multicolumn{2}{|c|}{ DIRECTA } & $\checkmark$ & $\checkmark$ & & $\checkmark$ & $\bullet$ & $\bullet$ & $\bullet$ & $\bullet$ & $\bullet$ & $\bullet$ \\
\hline \multirow{2}{*}{$\begin{array}{l}\mathrm{NÚ} \\
\mathrm{ME} \\
\mathrm{RO}\end{array}$} & \multicolumn{2}{|c|}{ UNITARIO } & & & & $\downarrow$ & $\diamond$ & $\diamond$ & $\diamond$ & $\downarrow$ & $\diamond$ & $\diamond$ \\
\hline & \multicolumn{2}{|c|}{ COLECTIVO } & 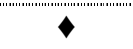 & 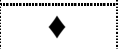 & • & & & & & & & \\
\hline \multirow{2}{*}{\begin{tabular}{|l|} 
GE \\
NER \\
RO
\end{tabular}} & \multicolumn{2}{|c|}{ MASCULINO } & $\downarrow$ & $\checkmark$ & 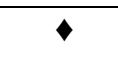 & $\checkmark$ & 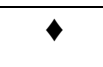 & & & & $\checkmark$ & $\checkmark$ \\
\hline & \multicolumn{2}{|c|}{ FEMENINO } & $\bullet$ & & & & & 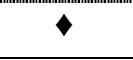 & $\checkmark$ & $\bullet$ & & \\
\hline \multirow{4}{*}{$\begin{array}{ll}\mathrm{D} & \\
\mathrm{E} & \\
\mathrm{S} & \\
\mathrm{C} & \\
\mathrm{R} & \\
\mathrm{I} & \\
\mathrm{P} & \\
\mathrm{CION} & \end{array}$} & \multicolumn{2}{|c|}{ FISICA } & & & & $\downarrow$ & 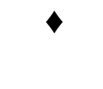 & 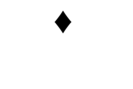 & $\bullet$ & $\bullet$ & 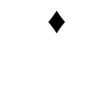 & • \\
\hline & \multicolumn{2}{|c|}{ KINESICA } & $\bullet$ & & & & & & & & $\bullet$ & $\bullet$ \\
\hline & \multirow[t]{2}{*}{$\begin{array}{l}\text { SICOLO- } \\
\text { GICA }\end{array}$} & PLANA & 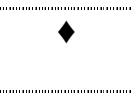 & $\checkmark$ & $\checkmark$ & $\checkmark$ & $\checkmark$ & $\checkmark$ & & & $\bullet$ & \\
\hline & & REDONDA & & & & & & & $\checkmark$ & $\checkmark$ & & $\bullet$ \\
\hline \multirow{2}{*}{$\begin{array}{l}\mathrm{D} \\
\text { E } \\
\text { S } \\
\text { A } \\
\mathrm{RR} \\
\mathrm{O} \\
\mathrm{LL} \\
\mathrm{O}\end{array}$} & \multicolumn{2}{|c|}{ ESTÁtICO } & $\bullet$ & 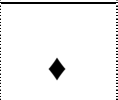 & 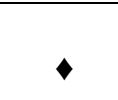 & $\bullet$ & $\bullet$ & & & & $\bullet$ & \\
\hline & \multicolumn{2}{|c|}{ DINAMICO } & & & & & & $\bullet$ & $\bullet$ & $\bullet$ & & $\bullet$ \\
\hline
\end{tabular}


La observación detenida del cuadro expuesto nos permite establecer las siguientes consideraciones:

1. Existe una recurrencia en los nombres de personajes presentados en las obras: Raquel, Daniel, judío y rabino. Mariene es el único nombre que se aleja del conjunto, pues Sara si bien no se repite, es un nombre propio de la literatura bíblica judía.

2. Las cinco primeras obras muestran personajes muy similares en cuanto a los aspectos distinguidos en nuestro estudio. Es decir, en general son personajes secundarios, masculinos, de descripción sicológica plana y de desarrollo estático.

3. Las cuatro obras siguientes cambian la constante y aparecen personajes protagónico, femeninos, con descripción física, sicológica redonda y desarrollo dinámico.

4. La aparición de los personajes es tanto directa como indirecta.

5. Los únicos tres personajes protagónicos, Mariene, Sara y Daniel Morton, tienen como semejanza fundamental ser presentados como personajes buenos y hermosos.

6. Los personajes antagonistas masculinos son decididamente perversos, con un gran apoyo de la descripción física y sicológica plana. En cambio el personaje antagónico femenino es hermoso.

7. Las tres primeras obras muestran personajes colectivos y las demás presentan personajes unitarios que, sin embargo, tienen matices colectivos, ya sea por cercanía de nombres o porque en las obras son considerados como "ejemplos" del grupo judío. Mariene es el único personaje propiamente "unitario", recordemos que en esta obra se menciona su condición de "hebrea" en vez de judía y solo una vez aparece su condición de origen.

8. Todos los personajes femeninos, con excepción de Rachel del "Cantar del Mío Cid", poseen la descripción física centrada en la belleza, por esta razón ninguno de estos personajes es considerado en tanto "judía" sino en tanto "hebrea". Este cambio en la nominación crea un puente entre la maldad y fealdad del grupo judío y la nueva posibilidad de la conversión al cristianismo, y así vemos que dos de estos personajes, Raquel y Sara, tienen un desarrollo dinámico al partir como hebreas y terminar como cristianas. 
9. La descripción kinésica se evidencia pocas veces, sin embargo complementa la descripción física y sicológica que aparece con abundancia. Esta descripción kinésica dice relación con el gesto de inclinación del cuerpo, ya sea por servilismo, ocultamiento, meticulosidad, etc.

10. La descripción sicológica es fundamentalmente plana y todas las descripciones de este tipo se estructuran en relación a rasgos negativos: avaricia, ignorancia, estupidez, soberbia, adulterio, hipocresía, sacrilegio.

11. Tanto los personajes con desarrollo estático como aquellos de desarrollo dinámico tienen como fin de su conflicto situaciones negativas: engaño en el "Cantar del Mío Cid", confusión en "El auto de los reyes magos" y "Los baños de Argel"; en el resto de las obras la muerte es el fin del personaje, incluso de aquellos convertidos al cristianismo.

12. Si bien "El mayor monstruo del mundo" presenta un personaje peculiar, apartado un poco del resto de nuestros personajes de estudio, nos muestra claramente el concepto del "sino"; Mariene está destinada a morir y, consecuentemente, muere. Ya en "Los baños de Argel" se mencionaba la "maldición eterna" que cae sobre lo judío. Así, el gran error que se discute en "El auto de los reyes magos" (s. XII), continúa operando en el resto de las obras, inclusive en el siglo XIX, donde la novela "Gloria" muestra que un judío bueno y hermoso continúa siendo un judío, es decir, un ser destinado a causar daño y muerte.

Hemos revisado obras muy diversas en género y época, sin embargo el personaje judío mantiene las bases de su construcción inicial, quizás la pequeña variante se produce en la aparición del género femenino que es fuente de belleza y conversión. Podemos concluir que ha existido en la tradición literaria de España un arquetipo judío que se utiliza cada vez como representación de lo negativo. 


\section{NOTAS}

${ }^{1}$ MARCHESE, A. Diccionario de retórica, crítica y terminología literaria. Traducido por Joaquín Forradillas. Barcelona : Ariel, 1989.

${ }^{2}$ GENETTE, G. La voz. En Genette, G. Figures III. Paris : Seuil, c1972.

${ }^{3}$ BREMOND, C. Logique du récit. Paris : Éditions du Seuil, c1973.

${ }^{4}$ FORMENT, María. Los repertorios extraverbales del personaje literario. Actas del $\vee$ Encuentro de Jóvenes Hispanistas. Las

${ }^{5}$ FORMENT, María. Op. Cit.

${ }^{6}$ RICO, F. Mil años de poesía española. Barcelona: Planeta, 1998.

${ }^{7}$ El cantar de Mío Cid. París ; Buenos Aires : Sociedad de Ediciones Louis-Michaud, [19--].

${ }^{8}$ Se puede acceder a un gran número de estudios sobre este episodio en SOLA-SOLE, J. Sobre árabes, judíos y marranos y su impacto en la lengua y literatura españolas. Barcelona: Puvill Libros, 1983

${ }^{9}$ El cantar del Mío Cid. Op.cit.

${ }^{10}$ El cantar del Mío Cid. Versión moderna obtenida del Sitio Web http://www.ebooksargentina.com/index.php?PHPSESS=9b6f9029ffa1c93f41e8a676c0a2add3\&mail =vani@uchile.cl\&pass=uregy\&dwncode=49\&image32.x=11\&image32.y=7

${ }^{11}$ Los orígenes: el auto de los reyes magos. En MARBÁN, E. El teatro español medieval y del renacimiento. New York : Las Américas, 1971. p.15-34.

${ }^{12}$ Parte de este Capítulo fue publicado en el Sitio Web http://www.geocities.com/urunuela33/lorenacampos/buenosmalos.htm

${ }^{13}$ BERCEO, G. Milagros de Nuestra Señora. Santiago : Nascimento, 1974

${ }_{15}^{14}$ Milagro III. Op.cit.

${ }^{15}$ Milagro XI Op.cit.

${ }^{16}$ Más información del EXEMPLUM EN: SÁNCHEZ DE VERCIAL, C. Libro de los exenplos por a. b. c. Edición crítica por John Esten Keller. Vocabulario etimológico / por Louis Jennings Zahn. Madrid : Consejo Superior de Investigaciones Científicas, 1961.

${ }^{17}$ LE GOFF, J. El judío en los exempla medievales. El caso del Alphabetum Narrationum. En LE GOFF, J. Lo maravilloso y lo cotidiano en el occidente medieval. Barcelona : Gedisa, 1986.

${ }^{18}$ Cantigas de Santa María. Alfonso X. Real Academia Española. Madrid: 1990.

${ }^{19}$ GAYANGOS, P. Escritores en prosa anteriores al siglo XV. Madrid : M. Rivadeneyra -ImpresorEditor, 1860.

${ }^{20}$ BERCEO, G. Milagros de Nuestra Señora. Santiago : Nascimento, 1974

${ }^{21}$ Cantigas de Santa María. Alfonso X. Real Academia Española. Madrid: 1990. 
${ }^{22}$ La danza de la muerte : códice del Escorial. Grabados de Holbein ; edición, prólogo y glosário de F. A. de Icaza. Editorial: Madrid : [s. n.], 1920

${ }^{23}$ CERVANTES, S. Los baños de Argel. En CERVANTES, S. Comedias y entremeses. Madrid: Calpe, 1940 v.3

${ }^{24}$ Ver: http://www.islaternura.com/APLAYA/NoEresEIUnico/cLETRA/Cervantes/CervantesBIO.htm

${ }^{25}$ http://www.cervantes.es/internet/gab/biografia_cervantes/obras/teatro/tea31a.htm

${ }^{26}$ Recomiendo para este aspecto de la obra cervantina revisar Maguén-Escudo, № 129, año 2003 en donde se publican interesantes estudios de la relación Judaísmo/Cervantes.

${ }^{27}$ VEGA, L. Las paces de los reyes, y judía de Toledo. En VEGA, L. Comedias escogidas de Frey Lope Félix de Vega Carpio. Madrid : M. Rivadeneyra, 1884, Vol. III

${ }^{28}$ CALDERÓN, P. El mayor monstruo del mundo. En CALDERÓN, P. El mayor monstruo del mundo; El príncipe constante. Buenos Aires : Espasa Calpe, 1952.

${ }^{29}$ BÉCQUER, G. La rosa de Pasión. En BÉCQUER, G. Rimas y leyendas. Santiago de Chile: Andrés Bello, impresión de 1991. p-120-124.

${ }^{30}$ Ver sub capítulo 2.3.3.

${ }^{31}$ PÉREZ ,B. Gloria. Buenos Aires : Losada, 1945

${ }^{32}$ Ver : SOLA-SOLE, J. Sobre árabes, judíos y marranos y su impacto en la lengua y literatura españolas. Barcelona: Puvill Libros, 1983; NES-EL, Moshe. Fuentes del pensamiento judío contemporaneo. Jerusalem : Organización Sionista Mundial, Departamento de Educación y Cultura en la Diaspora, 1984; CANSINO ASSENS, R. Los judíos en la literatura española. Buenos Aires:Columna, 1937; Lo viejo y lo nuevo de la imagen del judío. En Una era de transición №6. Israel:Universidad Abierta, 1981, y muchas obras más.

${ }^{33}$ Ver Cuadro 1, p.2 


\section{Bibliografía}

ALFONSO X. Cantigas de Santa María. Real Academia Española. Madrid: 1990.

ASSENS, R. Los judíos en la literatura española. Buenos Aires, Columna, 1937.

BÉCQUER, G. La rosa de Pasión. EN: Rimas y leyendas. Santiago de Chile: Andrés Bello, impresión de 1991.

BERCEO, G. Milagros de Nuestra Señora. Santiago, Nascimento, 1974

BREMOND, C. Logique du récit. Paris : Éditions du Seuil, c1973.

CERVANTES, S. "Los baños de Argel". EN: Comedias y entremeses. Madrid, Calpe, 1940 v.3

CALDERÓN, P. "El mayor monstruo del mundo". El mayor monstruo del mundo; El príncipe

constante. Buenos Aires, Espasa Calpe, 1952.

El cantar de Mío Cid. París - Buenos Aires, Sociedad de Ediciones Louis-Michaud, [19--].

El cantar del Mío Cid. Versión moderna obtenida del Sitio Web:

ttp://www.ebooksargentina.com/index.php?PHPSESS=9b6f9029ffa1c93f41e8a676c0a2add3\&mail= vani@uchile.cl\&pass=uregy\&dwncode=49\&image32. $x=11$ \&image $32 . y=7$

FORMENT, María. "Los repertorios extraverbales del personaje literario". Actas del V Encuentro de Jóvenes Hispanistas, Las Palmas de Gran Canaria, 25, 26 y 27 de octubre de 1995 / coord. Por Victoriano Santana Sanjurjo, Ana Isabel Mendoza de Benito, Asunción Rodríguez Viera, Antonio Alcántara Manzano, José Carlos Morales Umpiérrez, 1997, págs. 17-24

GAYANGOS, P. Escritores en prosa anteriores al siglo XV. Madrid, M. Rivadeneyra -ImpresorEditor, 1860.

GENETTE, G. La voz. En Genette, G. Figures III. Paris, Seuil, c1972.

MARCHESE, A. Diccionario de retórica, crítica y terminología literaria. Traducido por Joaquín Forradillas. Barcelona, Ariel, 1989.

NES-EL, Moshe. Fuentes del pensamiento judío contemporáneo. Jerusalem, Organización Sionista Mundial, Departamento de Educación y Cultura en la Diáspora, 1984;

La danza de la muerte : códice del Escorial. Grabados de Holbein, edición, prólogo y glosário de F. A. de Icaza. Editorial, Madrid, [s. n.], 1920 
LE GOFF, J. "El judío en los exempla medievales. El caso del Alphabetum Narrationum". En Lo maravilloso y lo cotidiano en el occidente medieval. Barcelona, Gedisa, 1986.

“Lo viejo y lo nuevo de la imagen del judío". En: Una era de transición №6. Israel: Universidad Abierta, 1981.

"Los orígenes: el auto de los reyes magos". En MARBÁN, E. El teatro español medieval y del renacimiento. New York, Las Américas, 1971. p. 15-34.

PÉREZ ,B. Gloria. Buenos Aires, Losada, 1945

RICO, F. Mil años de poesía española. Barcelona, Planeta, 1998.

SÁNCHEZ DE VERCIAL, C. Libro de los exenplos por a. b. c. Edición crítica por John Esten Keller. Vocabulario etimológico / por Louis Jennings Zahn. Madrid, Consejo Superior de Investigaciones Científicas, 1961.

SOLA-SOLE, J. Sobre árabes, judíos y marranos y su impacto en la lengua y literatura españolas. Barcelona: Puvill Libros, 1983;

VEGA, L. "Las paces de los reyes, y judía de Toledo". EN: Comedias escogidas de Frey Lope Félix de Vega Carpio. Madrid, M. Rivadeneyra, 1884, Vol. III 